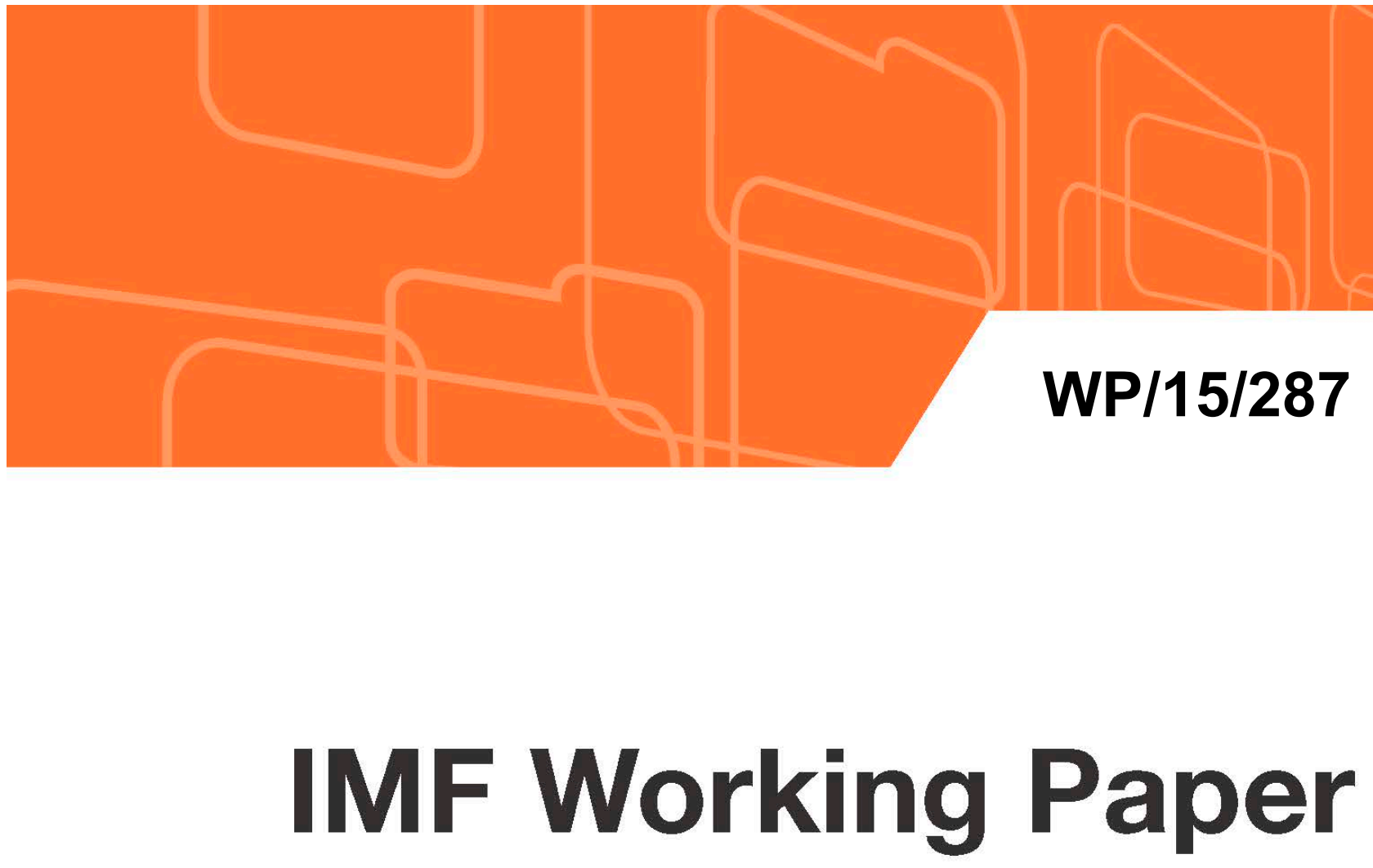

\title{
The Impact of Unconventional Monetary Policy Measures by the Systemic Four on Global Liquidity and Monetary Conditions
}

by Yevgeniya Korniyenko and Elena Loukoianova 


\title{
IMF Working Paper
}

Statistics Department

\section{The Impact of Unconventional Monetary Policy Measures by the Systemic Four on Global Liquidity and Monetary Conditions}

\section{Prepared by Yevgeniya Korniyenko and Elena Loukoianova}

Authorized for distribution by Robert York

December 2015

IMF Working Papers describe research in progress by the author(s) and are published to elicit comments and to encourage debate. The views expressed in IMF Working Papers are those of the author(s) and do not necessarily represent the views of the IMF, its Executive Board, or IMF management.

\begin{abstract}
The paper examines the impact of unconventional monetary policy measures (UMPMs) implemented since 2008 in the United States, the United Kingdom, Euro area and Japanthe Systemic Four - on global monetary and liquidity conditions. Overall, the results show positive significant relationships. However, there are differences in the impact of the UMPMs of individual S4 countries on these conditions in other countries. UMPMs of the Bank of Japan have positive association with global liquidity but negative association with securities issuance. The quantitative easing (QE) of the Bank of England has the opposite association. Results for the quantitative easing measures of the United States Federal Reserve System (U.S. Fed) and the ECB UMPMs are more mixed.

JEL Classification Numbers: E43, E51, F42, G28

Keywords: unconventional monetary policy, monetary aggregates, global liquidity, spillovers, capital flows.

Author's E-Mail Address: ykorniyenko@imf.org, eloukoianova@,imf.org

\footnotetext{
${ }^{1}$ The authors would like to thank Sally Chen, Gary Jones, Robert Heath, Robert York, and participants of the seminar of the IMF's Statistics Departments for their valuable comments. We are also grateful to James Chan, Olena Ftomova, and Naman Khandelwal for excellent research assistance. The views expressed here are those of the authors and not necessarily those of the IMF. All errors and omissions are our own.
} 


\section{Contents Page}

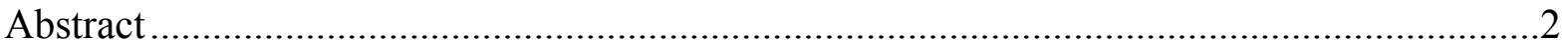

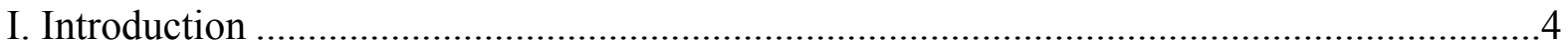

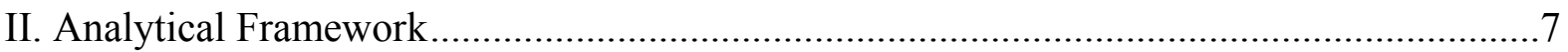

III. Data and Descriptive Analysis of UMPM Transmission Channels....................................9

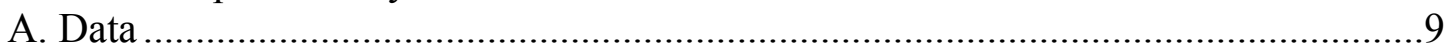

B. Descriptive Analysis of UMPM Transmission Channels .......................................10

UMPM Programs and Macro-financial Vulnerabilities...................................15

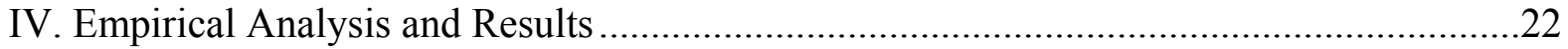

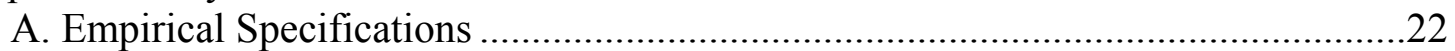

B. Impact on Global Liquidity, Global Monetary Aggregates, and Cross-Border

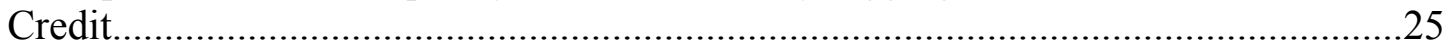

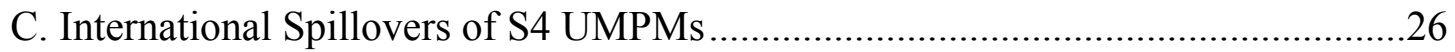

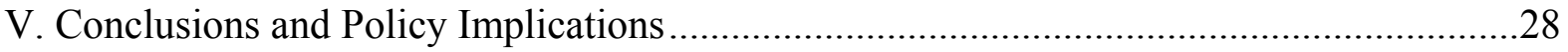

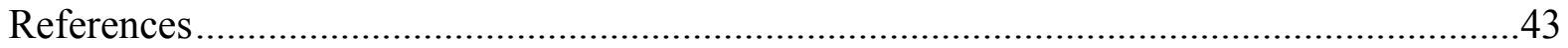

Tables

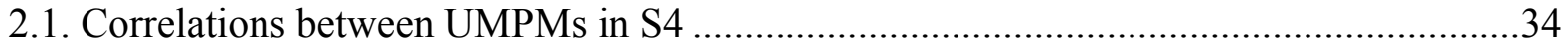

2.2. Summary Statistics for Two Samples ……………….....................................................

3.1. Impact of S4 UMPMs on Global Liquidity Conditions..................................................36

3.2. Impact of UMPM Programs on Broad Money Growth ....................................................... 37

3.3. Impact of UMPM Programs on Broad Money Growth .......................................................38

3.4. Impact of UMPM programs on NFC Deposits Growth...................................................39

3.5. Impact of UMPM Programs on NFC Deposits Growth.................................................40

3.6. Impact of UMPM Programs on NFC Securities' Issuance ...............................................4

3.7. Impact of UMPM Programs on NFC Securities' Issuance ..............................................42

Figures

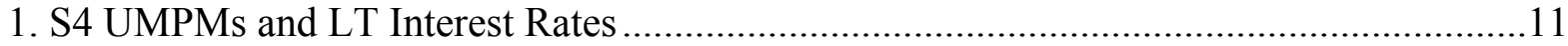

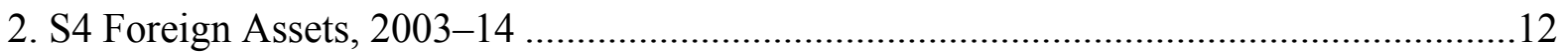

3. Rest of the World Foreign Assets and Liabilities, 2003-134 ..........................................14

4. Monetary Authority and Banking System Total Assets ...................................................15

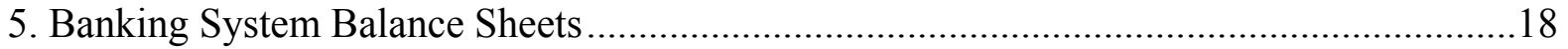

6. Brazil vs. Turkey Financial Assets and Liabilities, 2005 to H1 2014 ...............................20

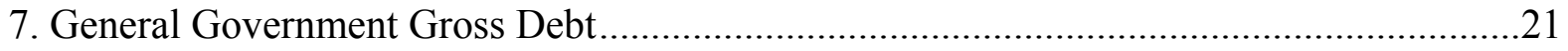

Annexes

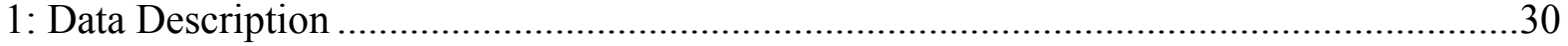

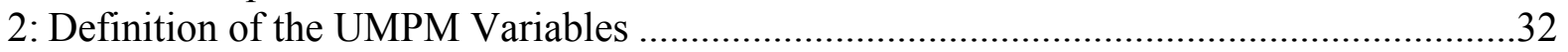

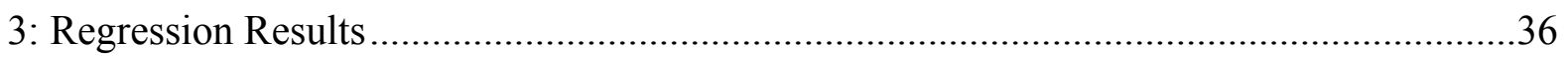




\section{INTRODUCTION}

In recent years, central banks in several systemically important countries have adopted unconventional monetary policy measures (UMPMs) - ranging from large scale purchases of public and private debt securities to direct lending to banks - designed to inter alia, repair the monetary transmission mechanism by ensuring depth and liquidity in financial markets and provide monetary accommodation at the zero lower bound of policy interest rates. ${ }^{2}$ One distinguishing feature of UMPMs, which has also been referred to as quantitative easing (QE), is that the central bank actively uses its balance sheet to influence market prices and conditions beyond the use of a short-term or "policy" interest rate. ${ }^{3}$

As a result of these policies, the balance sheets of the central banks implementing the UMPM programs expanded significantly over the period 2008-14. ${ }^{4}$ This has led to large injections of money into the economy through increased reserves (which, by a "money multiplier," increased broad money), ${ }^{5}$ as well as introduction of negative interest rates for some policy instruments in some advanced countries. ${ }^{6}$ With money and securities being imperfect substitutes, these programs resulted in portfolio rebalancing of assets of the United States, the United Kingdom, Euro area, and Japan - the Systemic Four (S4) — banks and corporations, which in turn increased asset prices. ${ }^{7}$ Investors responded by acquiring more risky assets outside the S4 that became relatively more attractive compared with S4 government bonds

\footnotetext{
${ }^{2}$ For more details on UMPM goals, instruments, channels and effectiveness see IMF (2013b).

${ }^{3}$ Borio and Disyatat (2010).

${ }^{4}$ For instance, the cumulative balance sheet change over 2007-14 of the Federal Reserve, the Bank of Japan and the Bank of England amounted to 20 percent, 35 percent, and 17 percent of GDP, respectively. In comparison, the net increase in assets of the European Central Bank has been modest over a similar period as the extent of the QE program was not yet underway.

${ }^{5}$ QE/UMPM can work as an extended form of open market operations. Nowadays, monetary policy mainly acts by setting a target for the overnight interest rate in the interbank money market and adjusting the supply of central bank money to that target through open market operations. To minimize the risk exposure of the central bank's balance sheet, all liquidity-providing operations normally take place in the form of reverse transactions against a menu of eligible collateral. As interest rates hit zero lower bound, additional monetary stimulus can be achieved in three complementary ways: (i) by guiding medium-to long-term interest rate expectations, (ii) by changing the composition of the central bank's balance sheet, and (iii) by expanding the size of the central bank's balance sheet. To study the impact of the later is a particular focus of this paper.

${ }^{6}$ Friedman (2013).

${ }^{7}$ Bowdler and Radia (2013), Farmer R. E. A. (2012, 2013).
} 
and securities: capital outflows from the S4 rebounded leading to increased inflows and issuance of new securities in emerging market economies (EMEs). ${ }^{8}$

The overall effect of the S4 UMPMs on the rest of the world (RoW) liquidity and monetary conditions is not yet clear, as positive trade and capital spillovers may likely be accompanied by increased macro-financial vulnerabilities. While empirical studies find evidence of significant spillovers of monetary easing in the S4 on the RoW through trade and finance channels, ${ }^{9}$ research on the impact of the S4 UMPMs on the RoW banks' balance sheets, liquidity, and money supply is still in an embryonic stage. ${ }^{10}$

Indeed, the substitution of cross-border banking flows with portfolio flows of non-banks does raise new concerns about financial vulnerabilities. ${ }^{11}$ The growing role of non-financial corporations (NFCs) as de facto "financial intermediaries" may reduce the effectiveness of macroprudential policies and limit the ability of policy makers to respond to future shocks. Seen from a broader perspective, such UMPM programs might also lead to a loosening of fiscal discipline and shifts in the allocation of resources. ${ }^{12}$ In this context, the overall effect of the S4 UMPMs on the RoW is likely to be dependent on both the specific policy frameworks of affected countries and each UMPM program. ${ }^{13}$ Likewise, the affect of S4 UMPMs reversals on the RoW, i.e., monetary policy normalization, could also be varied. ${ }^{14}$

Against this background, this paper attempts to break new ground in empirically investigating UMPM spillovers on global liquidity and monetary conditions and financial sector balance sheets in other countries. In particular, we focus our analysis on spillovers from S4 monetary policy easing (conventional and QE/UMPMs) on the RoW's monetary aggregates, banks' balance sheets (NFC deposits), and NFC securities issuances. We also assess potential threats stemming from UMPMs unwinding to the RoW. To the best of our

\footnotetext{
${ }^{8}$ For a discussion on the QE/UMPM impact on cross-border capital flows, see Ahmed and Zlate (2013), Cerutti (2014), Fratzcher et al. (2012), Lo Duca, Nicoletti, and Martinez (2014).

${ }^{9}$ For example, see Bean (2013), Cerutti et al, (2014), Chen et al. (2012), Dedola (2012), Fratzscher, Lo Duca and Straub (2013), Morgan (2011), and Subramanian (2014).

${ }^{10}$ Chung et al. (2014).

${ }^{11}$ For instance, see BIS (2010, 2013), Bruno and Shin (2012, 2013), IMF GFSR (2014), Halm, Shin, and Shin (2013), Shin and Zhao (2013), and Turner (2013).

${ }^{12}$ Filardo and Yetman (2012), and Iwata and Takenaka (2011).

${ }^{13}$ Burns et al. (2014), IMF Spillover Reports (2013 and 2014).

${ }^{14}$ Burns et al. (2014), IMF (2014b).
} 
knowledge, this topic remains largely unexplored, which is a major gap in understanding of UMPM spillovers/leakages.

The paper focuses on specific QE programs and UMPMs implemented by the S4: (i) the large-scale assets purchase (LSAP) by the U.S. Fed, split by type of securities into purchases of U.S. treasuries, mortgage backed securities (MBS), and securities of government sponsored enterprises (GSE); (ii) the QE strategy implemented by the Bank of England (BoE); (iii) the assets purchase program of the Bank of Japan (BoJ); and (iv) the ECB's government bond purchases (phases one and two), the ECB's three-year long-term refinancing operation (LTRO), and the ECB's securities market program (SMP).

We find positive and statistically significant relationships between UMPM implementation and global liquidity and monetary conditions in terms of global NFC deposit growth (including China), banks' cross-border flows, and issuance of securities (particularly in foreign currency). We also find significant differences in the impact of the UMPMs implemented by individual S4 on broad money, NFC deposits, and securities issuance in EMEs. The BoJ's asset purchases programs appear to have a positive impact on global liquidity and other countries' monetary conditions, while they appear to have a negative association with issuance of securities. In contrast, the effects of the QE program implemented by the BoE have strong negative association with global liquidity, measured by broad money and NFC deposits and positive impact on issuance of NFC securities. Results for QE implemented by the U.S. Fed and ECB UMPMs are mixed. ${ }^{15}$

The paper develops a new quarterly dataset covering the period Q1:2002-Q2:2014, leveraging monetary data reported by IMF member countries through the IMF's standardized report forms (SRFs), which have the advantage of providing a consistent set of definitions based on the IMF's Monetary and Financial Statistics Manual, and can be replicated over time and across countries using officially reported data. Core and non-core liabilities of banks are computed using detailed SRF data reported to the IMF on a confidential basis. Leveraging the IMF's SRFs is our major advantage, relying on broad money as monetary aggregate, which is comparable across SRF reporting countries. In contrast, other studies have typically relied on countries' self-reported monetary aggregates under more traditional classifications (e.g., M0, M2, etc.) subject to different national definitions, which make cross-country comparisons less meaningful.

\footnotetext{
${ }^{15}$ The use of the Eurosystem balance sheet was evolving over time from a relatively passive approach, with liquidity provision being determined by the needs of the Eurosystem counterparties, to more active management of the size of composition of balance sheet assets. For more details see "The role of the central bank balance sheet in monetary policy", ECB Economic Bulletin, Issue 4, 2015.
} 
The paper is organized as follows. Section II describes the analytical framework. Section III presents the data empirical analysis. Section IV summarizes the main findings and empirical results, and Section V concludes.

\section{AnAlytical Framework}

During normal times, the central bank is neither involved in direct lending to the private sector or the government, nor in outright purchases of government bonds, corporate debt, or other types of debt instruments. To provide sufficient monetary stimulus to the economy during downturns, contain inflationary pressures during upturns, and to ensure the sound functioning of the money market, the central bank is steering the level of the key interest rate. When interest rates are brought down to zero due to powerful economic shocks, it is impossible to cut policy rates further to achieve additional monetary stimulus, and thus recourse to UMPMs is warranted. ${ }^{16}$

Empirical assessments of UMPMs are challenging, since there is no generally accepted theoretical framework. Hence, the empirical analysis must be carefully designed to avoid imposing theoretical restrictions to mine the data for significant results. As UMPMs were not entirely unanticipated (with the possible exception of the first round of QE in the United States), studies that place large weight on announcement effects may arrive at misleading results. We do not directly take into account the announcement and/or communication channel of the UMPMs, as it was changing or evolving over time and worked through changes in supply of different assets. ${ }^{17}$ The focus of this work is on the impact of stock effects of the programs, i.e., to what extent persistent shift in long-term bond yields (interest rates), as a result of UMPMs expansion of the S4 central banks' balance sheets, impacted global liquidity, monetary conditions, and financial sector balance sheets in other countries. ${ }^{18}$ We assess the impact of these programs using a cross-country comparable broad money variable, banks' balance sheet variables (non-core liabilities as measured by NFC deposits), and NFC issuance of securities.

As the use of QE/UMPMs has become prevalent, it is possible that the market began to anticipate new rounds of QE/UMPMs and factored them into the pricing of assets prior to

\footnotetext{
${ }^{16}$ However, UMPM may be warranted even when the policy interest rate is above zero if the monetary policy transmission mechanism is significantly impaired. Under these circumstances, central banks have two (not necessarily mutually exclusive) alternatives, namely (i) to reduce the short-term nominal interest rate even further than in normal conditions, and (ii) to act directly on the transmission mechanism by using nonconventional measures.

${ }^{17}$ Krishnamurthy and Vissing-Jorgensen (2011).

${ }^{18}$ The stock and flow effects of the US QE programs are analyzed by D'Amico and King (2013).
} 
their official announcement. ${ }^{19}$ Also, as UMPMs were implemented in response to the global crisis, they are endogenous to other macroeconomic variables. Therefore, thorough assessments of the macroeconomic effects of unconventional monetary policies would require a counterfactual (i.e., what would have happened absent policy action). ${ }^{20}$ Such an exercise would be primarily hypothetical, as there is no real empirical evidence or repeated experiment.

We believe, therefore, it is more appropriate to focus on the narrower question: the marginal effects of cross-border spillovers of the S4 UMPMs on other countries, controlling for global financial conditions and macroeconomic environment in individual countries (i.e. policy interest rate, exchange rate, inflation, GDP growth, etc.).

The importance of monetary aggregates and NFC deposits as a proxy for global liquidity and financial vulnerability indicators has been underscored in recent literature. ${ }^{21} \mathrm{~A}$ number of studies $^{22}$ emphasize the role of non-core liabilities of banks, as one of the vulnerability indicators.

We approach the question two-fold by conducting descriptive analysis of possible transmission channels and by using regression analysis.

Our regression analysis is also based on a two-step approach:

- First, we instrument long-term interest rates by the S4 UMPM programs to directly extract the variation in yields explained by implemented UMPMs over the period analyzed.

- Second, we elaborate on the S4 UMPM's global and country level impact. We briefly discuss the relationship between UMPMs in each of the S4 and the associated changes in global money supply, global NFC deposits (including China), global domestic or crossborder credit, and global issuance of international securities. Finally, we focus on UMPM spillovers on individual country liquidity and monetary conditions, focusing on broad money, bank balance sheet liabilities (core and non-core), and issuance of securities. The

\footnotetext{
${ }^{19}$ Nellis and College (2013).

${ }^{20}$ See IMF (2013) and Chen et al. (2015).

${ }^{21}$ Different concepts of global liquidity have been discussed in detail in Chung et al. (2014), Cerruti, Claessens and Ratnovski (2014), and IMF (2013c, 2014e).

${ }^{22}$ For example, Hahm, Shin, and Shin, (2013).
} 
countries are analyzed in various groupings or aggregations based on income levels depending on analytical needs.

\section{DATA AND DESCRIPTIVE ANALYSIS OF UMPM TRANSMISSION CHANNELS}

\section{A. Data}

The paper develops a new quarterly dataset covering the period Q1:2002-Q2:2014. The dataset consists of very detailed monetary and financial statistics (MFS) reported by IMF member countries through the IMF's SRFs, supplemented by the IMF's International Financial Statistics (IFS) and Balance of Payments (BoP) databases, the World Bank's external debt database, BIS data on international issuance of securities, and Dealogic data on issuance of bonds by country of residence. In addition, the dataset contains information on capital account openness, exchange rate regimes, overall institutional environment quality, and various measures of banking systems' structure and regulations. ${ }^{23}$

Our sample includes 131 countries, of which 28 are grouped as advanced and 103 emerging market and developing economies (including low-income countries). For the vast majority of countries in our sample, we utilize cross-country comparable and methodologically robust monetary series of broad money derived from the IMF's SRFs. ${ }^{24}$

To measure countries' funding liquidity, we use the monetary aggregate $L$, which is defined as the sum of deposits of NFCs in the banking system (a.k.a., "other depository corporations" or ODCs). ${ }^{25}$ The deposits of NFCs consist of transferable and other deposits included in the broad money aggregate, as well as transferable and other deposits excluded from the definition of broad money, both in local and foreign currency. ${ }^{26}$ In addition, we use banking system foreign liabilities and the BIS and Dealogic statistics on debt securities issuance.

\footnotetext{
${ }^{23}$ A full description of the dataset, including definitions of the variables and data sources is provided in Annex 1.

${ }^{24}$ For non-SRF reporting countries, we use broad money series when available and otherwise proxy the broad money series with M0, M2, M3, money, and quasi-money depending on data availability.

${ }^{25}$ See Chung et al. (2014) for the full definition and details.

${ }^{26}$ The breakdown of the NFC deposits follows the methodology and classification of the Monetary and Financial Statistics Manual (IMF, 2000), http:/www.imf.org/external/pubs/ft/mfs/manual/index.htm; and the Monetary and Financial Statistics Compilation Guide (IMF, 2008), http://www.imf.org/external/pubs/ft/cgmfs/eng/index.htm.
} 
To assess the impact of QE/UMPM policies, we consider specific UMPMs. ${ }^{27} \mathrm{We}$ define $\mathrm{QE} / \mathrm{UMPM}$ variables as changes in actual net asset purchases by the $\mathrm{S} 4$ central banks during Q1:2002-Q4:2013 and use it as an instrumental variable to isolate more directly the change in long-term yields that could be attributed to unconventional monetary policies in each of the S4 countries individually and the S4 as a whole. ${ }^{28}$

\section{B. Descriptive Analysis of UMPM Transmission Channels}

As discussed earlier, the primary purpose of the UMPMs was to restore the functioning of financial markets and intermediation and to provide further monetary policy accommodation at the zero lower bound in S4. However, these policies had spillover effects on the rest of the world through the traditional interest rate channel by reducing longer-term yields, significant capital outflows from S4, boosted global liquidity, portfolio rebalancing channel and impact on exchange rates, reserves, and real channels. Additionally, we will argue that transmission of the UMPMs contributed to increased macro-financial vulnerabilities in other countries.

S4 central bank balance sheet policies were designed to cope with domestic policy challenges; however, there were sizable leakages of these policies through cross-border transmission channels to other countries. ${ }^{29}$

- First, UMPMs may spillover cross-border through the traditional interest rate channel by reducing longer-term yields and encouraging investors to search for assets of similar maturities with higher risk-adjusted returns.

- Second, UMPMs could have portfolio rebalancing impacts domestically and crossborder. Central bank asset purchases changed the relative demand and prices of different securities, thus influenced investors' portfolio decisions through the portfolio balance channel. This might cause size and composition changes in private sector asset holdings.

- Third, sizable UMPM programs could have operated though boosting global liquidity. Persistently low interest rates and abundant liquidity could have created incentives for financial institutions in both advanced and emerging market economies to search for yields. In addition, QE/UMPMs could have had direct impact through the banking channel, as UMPM programs eased funding conditions and supported bank lending.

\footnotetext{
${ }^{27}$ Empirical research measures QE as dummy variable equal to one for the day of the QE policy announcement, as a surplus of assets purchased, or as a change in central bank balance sheet.

${ }^{28}$ A full description of the specific QE/UMPM programs that we consider and the methodology we use to identify UMPM related changes in long-term bond yields in our analysis are provided in Annex 2.

${ }^{29}$ Chen et al. (2013).
} 
- Last but not least, QE/UMPMs could have an impact on other countries via exchange rate, reserves, and real channels. ${ }^{30}$

The UMPMs implemented by the S4 and analyzed in this paper are negatively correlated with the nominal long term (LT) interest rates (Figure 1), confirming existing results of the empirical studies ${ }^{31}$ that show that UMPMs had significant impact on respective long-term government bond yields (LT interest rates). This suggests that S4 UMPMs contributed to the compression of long-term interest rates in S4, which prompted a materialization of rebounded private capital outflows from these countries (Figure 2).

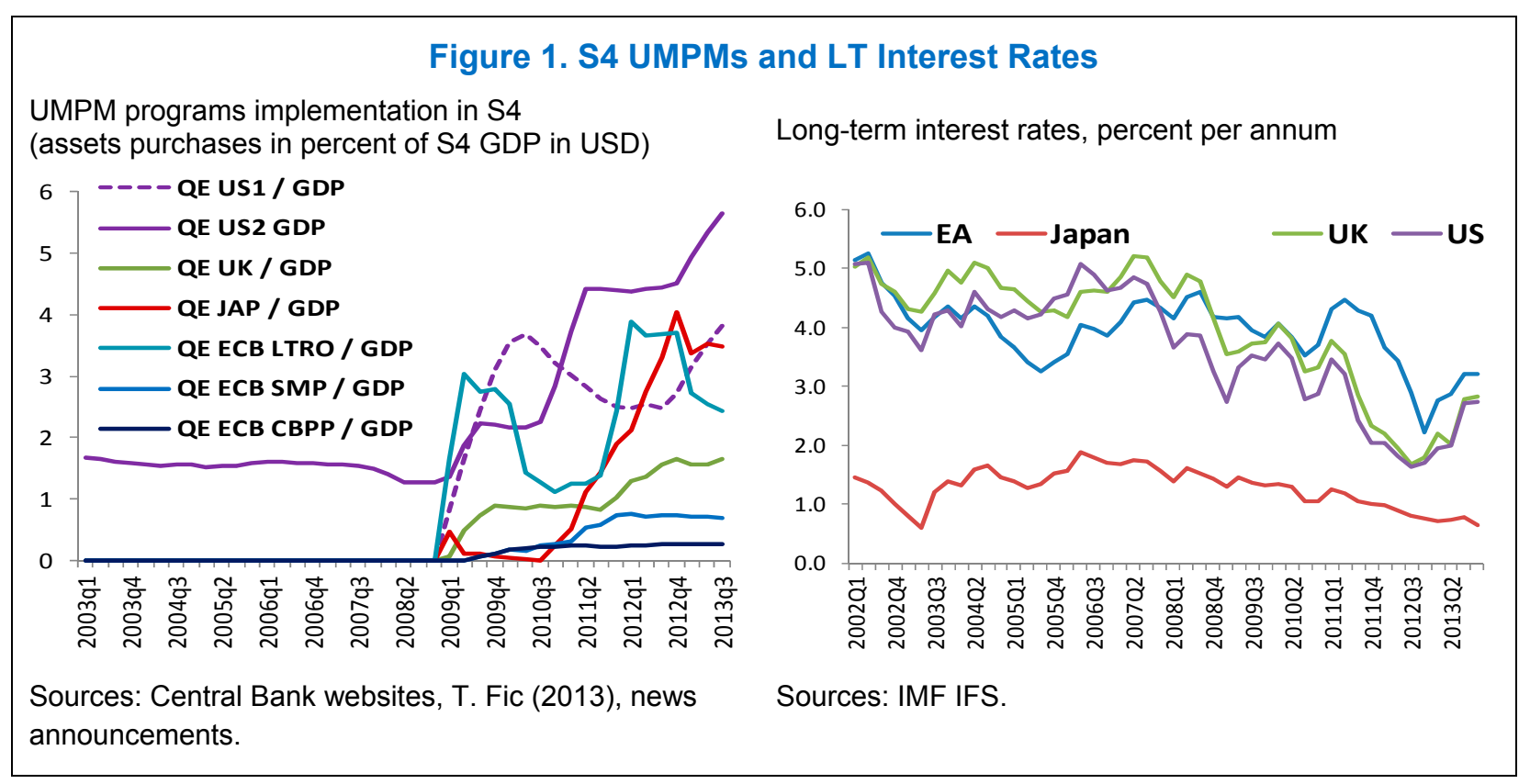

At the same time, not all types of S4 capital flows rebounded to the pre-crisis level. For example, gross private capital outflows after crisis in the Euro Area and the United States rebounded, but their levels remain significantly below the pre-crisis period. Private equity and other debt securities outflows, with exception of Japan, had rebounded the most (Figure 2), indirectly supporting the portfolio rebalancing channel of QE spillovers. As showed by Lo Duca, Nicoletti, and Martinez (2014), the U.S. QE had a large impact on corporate bond issuance globally, and especially in EMEs. At the same time, other investment assets from the United States, the United Kingdom, and the EA remain negative despite QE and ECB UMPMs, since banking systems of these countries continue rebuilding

\footnotetext{
${ }^{30}$ Cho and Rhee (2014), Ikeda, Medvedev, and Rama (2015), and Reed and Saghaian (2015).

${ }^{31}$ Gagnon et al. (2011), Krishnamarthy and Vissing-Jorgensen (2011), D’Amico and King (2013), D'Amico et al. (2012), Meaning and Zhu (2011), Swanson (2011), Hamilton and Wu (2012), Engen, Laubach, and Reifschneider (2015), Li and Wei (2013), and Ihrig et al. (2012).
} 
their balance sheets. This largely explains declining gross capital outflows from the Euro Area and the United Kingdom starting from Q2:2011. After a mediocre rebound, private capital outflows from the United Kingdom turned negative at the end of 2011, reflecting consolidation strategies of U.K. banks.

Against the prevailing trend of significant negative impact of advanced countries' bank deleveraging on EMEs' balance sheets, net private external assets of EMEs remain negative and increasing with the exception of two risk-off episodes after a collapse of Lehman and intensification of the crisis in the Euro Area. EMEs significantly intensified their borrowing from abroad in the form of equities and securities after 2009. During 2009-13, the purchase of EMEs' private securities tripled relative to the pre-crisis period of 2002-07. In addition, other external investment liabilities of EMEs (primarily cross-border bank credit) also rebounded strongly after 2009 (Figure 3).

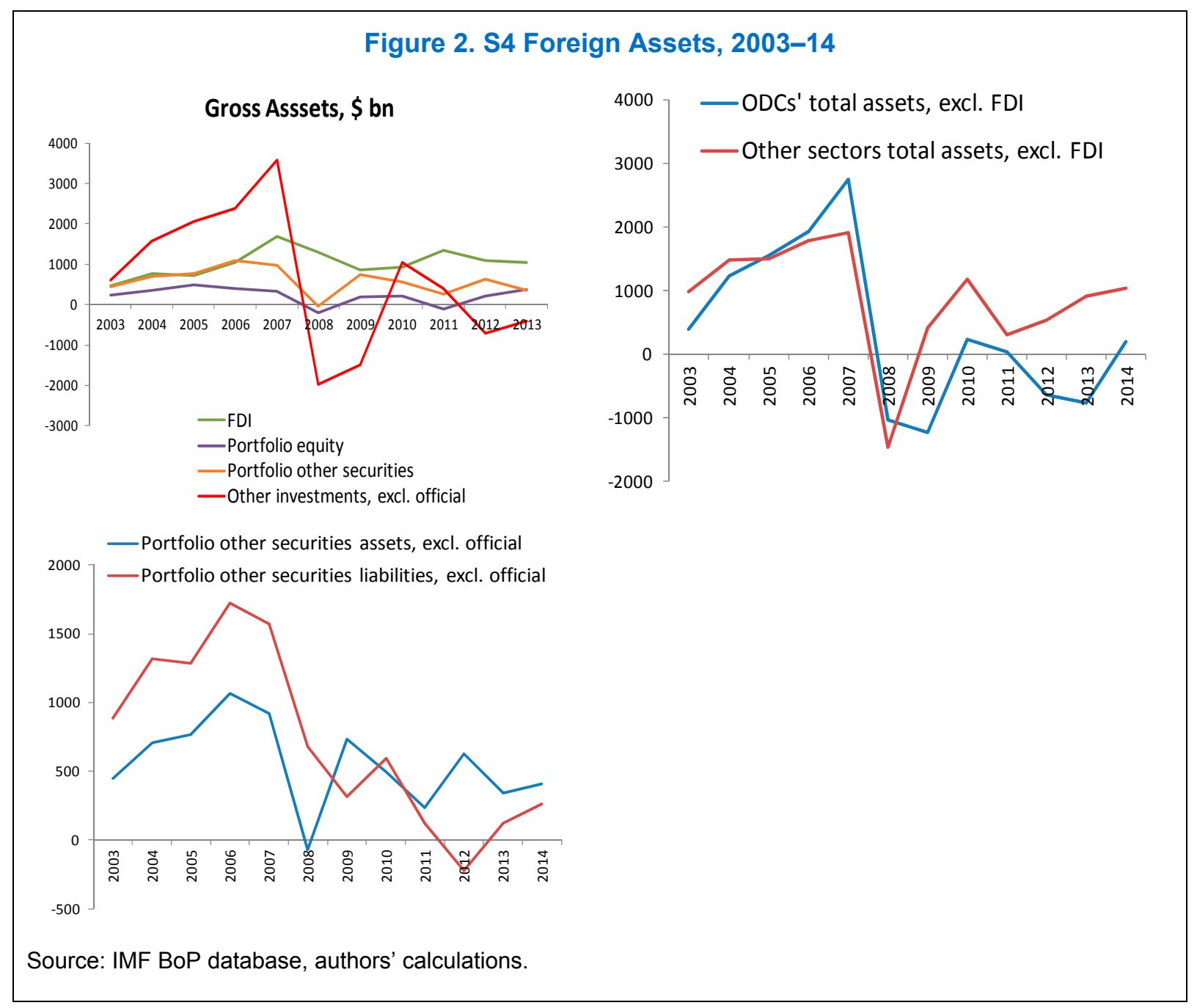

If anything, monetary easing and increased capital outflows from S4 have contributed to EMEs' liquidity. Additionally to domestic portfolio rebalancing, low interest rate 
environment and search for yield caused increased demand for EMEs public and private debt assets. The low interest rate environment and increased demand from S4 led to increased issuance of government securities in EMEs. These developments resulted in increased net public debt flows to EMEs. As shown in Figure 3, net public debt flows to EMEs (measured as total foreign assets less total foreign liabilities) became and remain significantly negative since 2009. 
Figure 3. Rest of the World Foreign Assets and Liabilities, 2003-14

(In billions of U.S. dollars)

Emerging and Developing countries net flows (total foreign assets - total foreign liabilities)

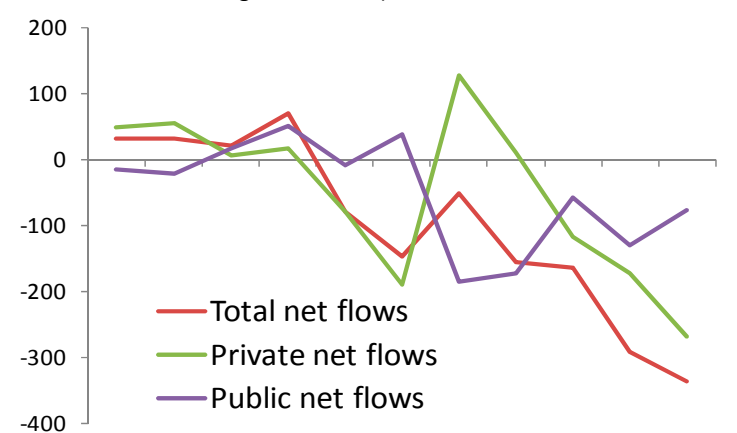

20032004200520062007200820092010201120122013

Emerging and Developing countries portfolio flows

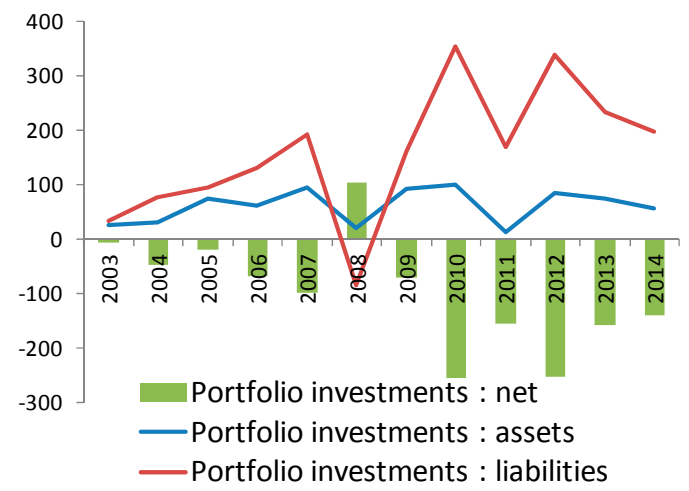

Emerging and Developing countries other investments flows

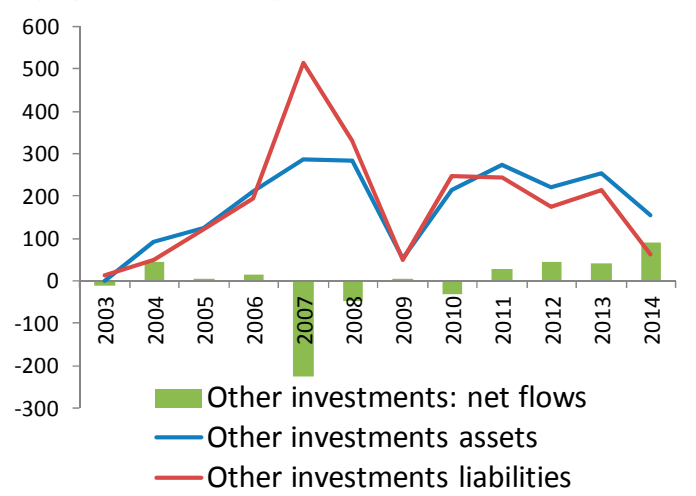

Advance Economies net flows (total foreign assets - total foreign liabilities), excl. S4

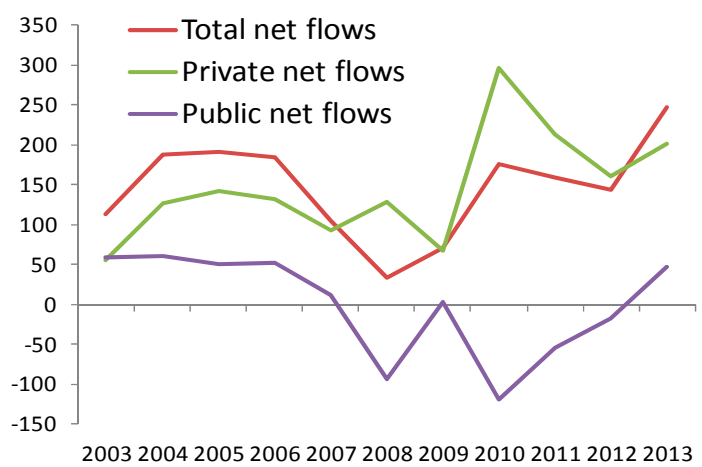

Advance Economies portfolio flows, excl. S4

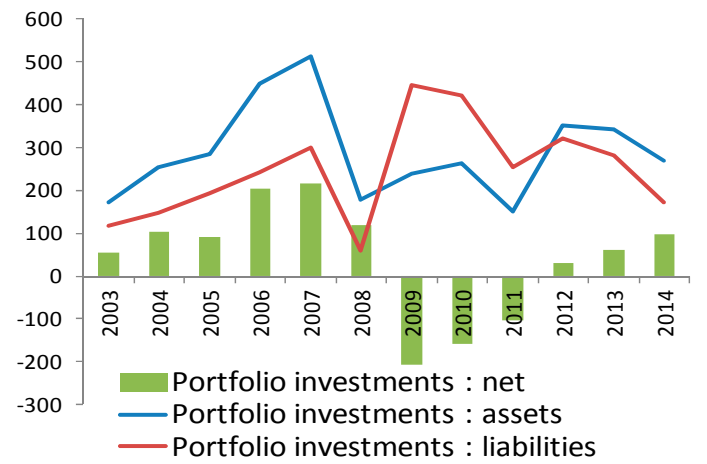

Advance Economies other investments flows, excl S4

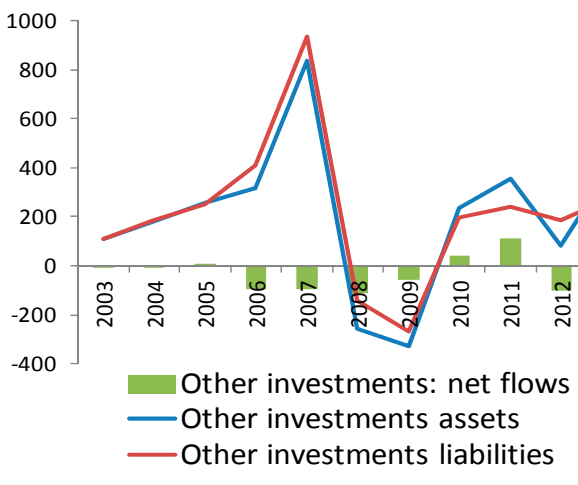

Source: IMF, Balance of Payments database.

Note: Data for country groupings calculated by summing flows across countries. 


\section{UMPM Programs and Macro-financial Vulnerabilities}

An analysis of domestic sources of liquidity shows that central banks in AMs injected significant amounts of liquidity to the financial markets during 2008-09 (Figure 4). The primary purpose of these transactions was to stabilize the financial system and provide liquidity to banks. However, since the end of 2010, AMs have continued injecting liquidity into their domestic economies as a substitute for liquidity provisions by banks.

Monetary authorities in EMEs and LICs have expanded their balance sheets significantly as well, as a result of an accumulation of foreign reserves and sterilization operations. Additionally, on average, banking systems in EMEs and LICs continue to expand their balance sheets rapidly. Indeed, the BIS credit-to-GDP gap measure ${ }^{32}$ has significantly widened recently for some EMEs, pointing to an increasing vulnerability and higher probability of future banking crises. Two factors may have contributed to this dynamic. Real GDP growth of EMEs and LICs declined since 2010 by more than one percentage point (from 4.8 to 3.6 percent). At the same time, banking system total assets in nominal terms continued to expand at a pace of about 15 percent on average during 2010-14.

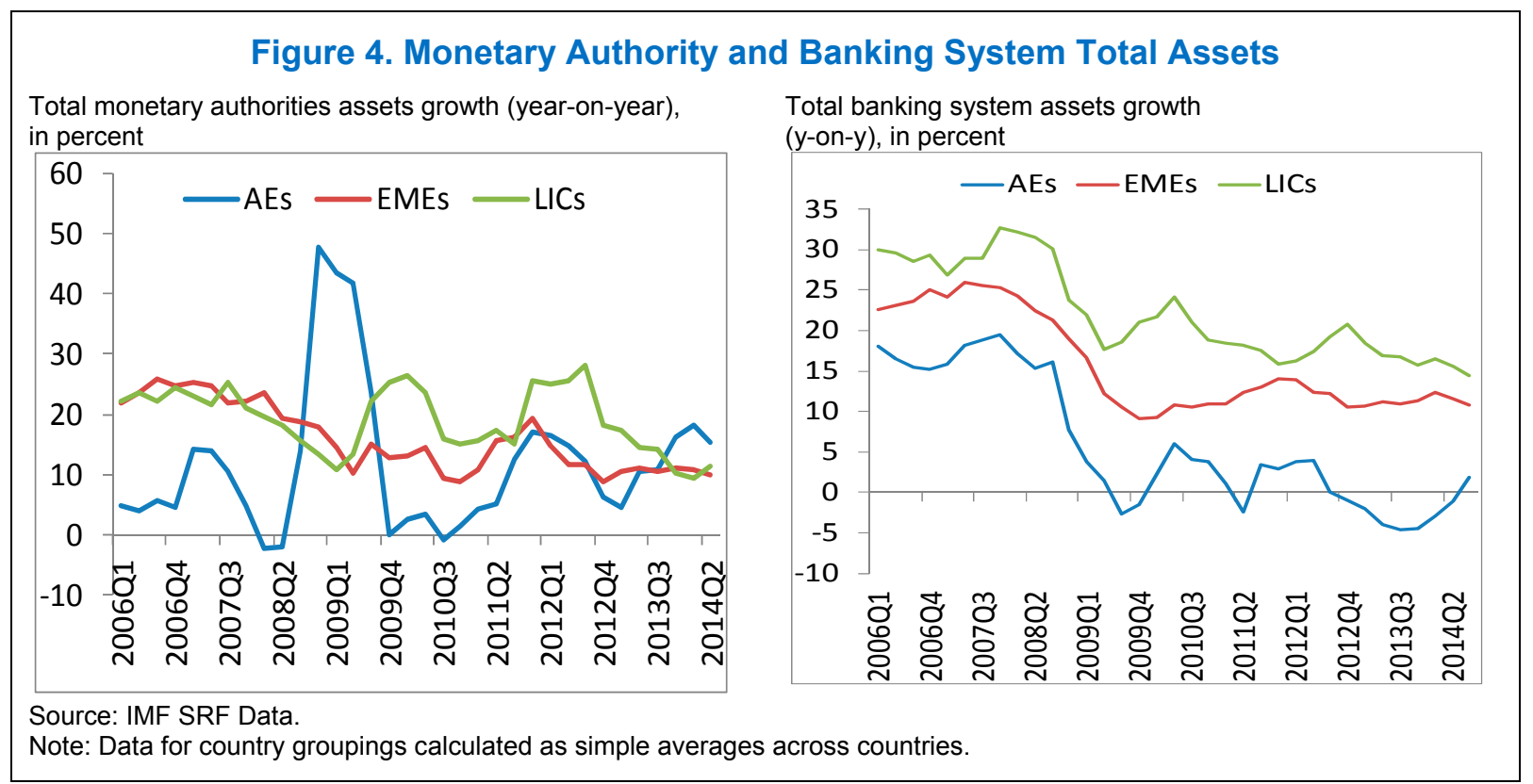

\footnotetext{
${ }^{32}$ The credit-to-GDP gap ("credit gap") is defined as the difference between the credit-to-GDP ratio and its long-term trend. Borio and Lowe $(2002,2004)$ first documented its property as a very useful early warning indicator (EWI) for banking crises. Their finding has been subsequently confirmed for a broad array of countries and a long time span that includes the most recent crisis. For more detail see Borio and Drehmann (2009), Fitch Ratings (2010), Behn et al. (2013), and Drehmann and Juselius (2014).
} 
Partial replacement of cross-border banking flows with portfolio flows of non-banks does raise additional concerns about financial vulnerabilities in the EMEs. ${ }^{33}$ The growing role of NFCs as de facto "financial intermediaries" may decrease the effectiveness of macroprudential policies and limit the ability of policy-makers to respond to future shocks. Furthermore, UMPM programs can entail economic costs: in particular, they could lead to misallocation of resources and risk loosening fiscal discipline. ${ }^{34}$ As a result, the overall effect of UMPMs on the RoW is likely to differ depending on the nature of each major QE or UMPM program and the fundamentals and policy frameworks of the affected countries. ${ }^{35}$

The detailed analysis of the information collected by the IMF in the SRF forms for ODCs does not show any immediate concerns for EMEs' banking systems; however, it highlights a potential build-up of vulnerabilities on banks' balance sheets (Figure 5). We analyze how capital outflows from S4 were allocated by the RoW banks. Within banks' balance sheets, borrowed liquidity can be allocated threefold: banks can (i) increase lending to their customers; (ii) invest in domestic or foreign securities; and/or (iii) hold money as vault cash or reserves within the central bank. The S4 UMPM impact on RoW countries' liquidity and monetary conditions will thus depend on the RoW banks' allocation scenario of global liquidity. ${ }^{36}$

Since the peak in Q4:2008, AE banks' leverage (excluding S4 banks) is decreasing, while banks in EMEs are slowly leveraging up by increasing their exposure equally to all sectors of the domestic economy. The stock of credit to the private sector in EMEs and LICs has decreased immediately after the crisis in part due to the deleveraging of European banks, however, this trend was reversed in 2011. The total stock of banking credit in EMEs is currently higher than pre-crisis (Figure 5).

Despite, significant changes to the liquidity regulation after the global financial crisis, there are no visible changes to banks liquidity in any of the three groups of countries (AEs, EMEs, and LICs). Banks in low-income countries continue to maintain the highest level of liquidity due to the high risk of doing business in historically underdeveloped markets.

\footnotetext{
${ }^{33}$ BIS (2010 and 2013), Bruno and Shin (2012 and 2013), GFSR (2014), Halm, Shin, and Shin (2013), Shin and Zhao (2013), and Turner (2013).

${ }^{34}$ Filardo and Yetman (2012), and Iwata and Takenaka (2012).

${ }^{35}$ Burns et al. (2014), and the IMF Spillover Report (2013 and 2014).

${ }^{36}$ As it is shown by Orlowski (2015), the relative allocation of borrowed liquidity affects inflation risk, market risk, and, potentially in countries with flexible exchange rates and large portfolio capital inflows, the exchange rate risk. Additionally, invested liquidity may exacerbate tail risks in financial markets by contributing to higher asset-price volatility.
} 
On the funding side, AEs has significantly reduced their reliance on wholesale funding (and in particular from abroad), while the picture is different for EMEs and LICs, making them more vulnerable to the interest rate and/or exchange rate shocks.

In addition, all groups of countries (AEs, EMEs, and LICs) on average increased their reliance on credit to the central bank and the government (Figure 5): investments which are safer but less profitable and in some cases, crowd out private investments.

As suggested by the analysis in this paper, abundant global liquidity might be responsible for increasing vulnerabilities, in particular for banking systems in LICs, as shown by gradual but steady increase in the share of wholesale and foreign funding in total funding on banks.

Nonetheless, banks in these countries maintain high liquidity and on balance they still have low leverage. This situation merits careful monitoring going forward.

The picture for EMEs is mixed as averages are masking increased vulnerabilities in some countries that are offset by positive developments in others. Consider two examples, Turkey versus Brazil: Brazil significantly decreased the share of nonresidents in total funding, while Turkey continues to increase its reliance on foreign funds. This in part explains the divergent path of non-core liabilities in the two countries and is in line with Chen (2015), who found a heterogeneous and unevenly distributed costs and benefits of U.S. monetary policy spillovers on this group of countries. 
Figure 5. Banking System Balance Sheets

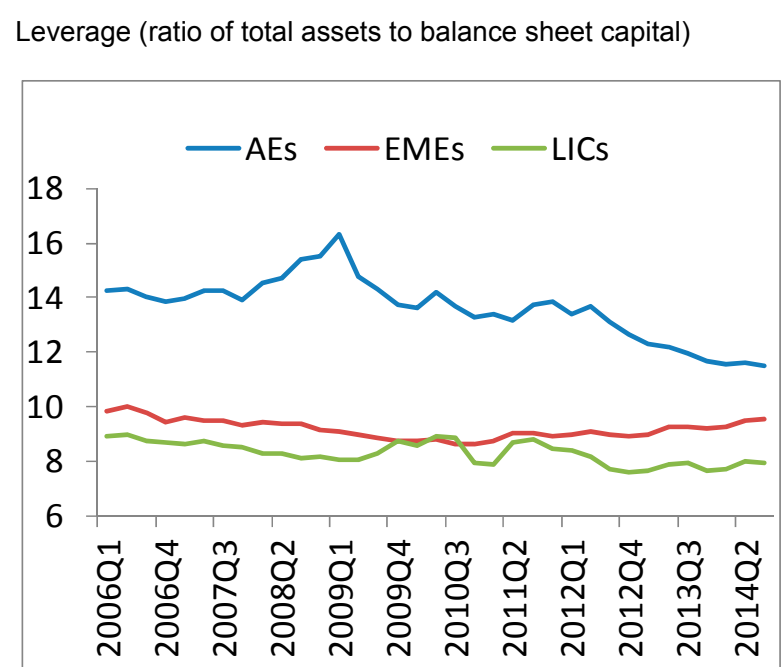

Liquidity (share of cash and government bonds in total assets)

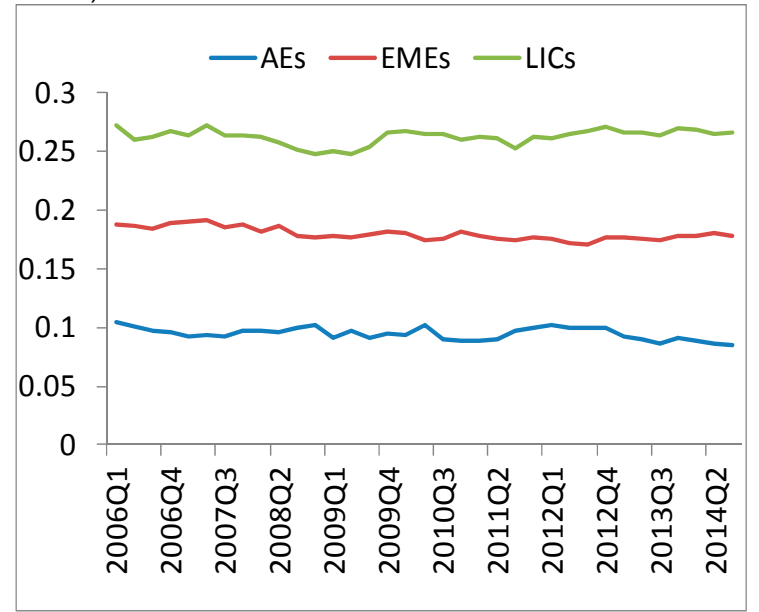

Credit to the private sector, as a share of total assets

Credit to the $\mathrm{CB}$ and government, as a share of total assets
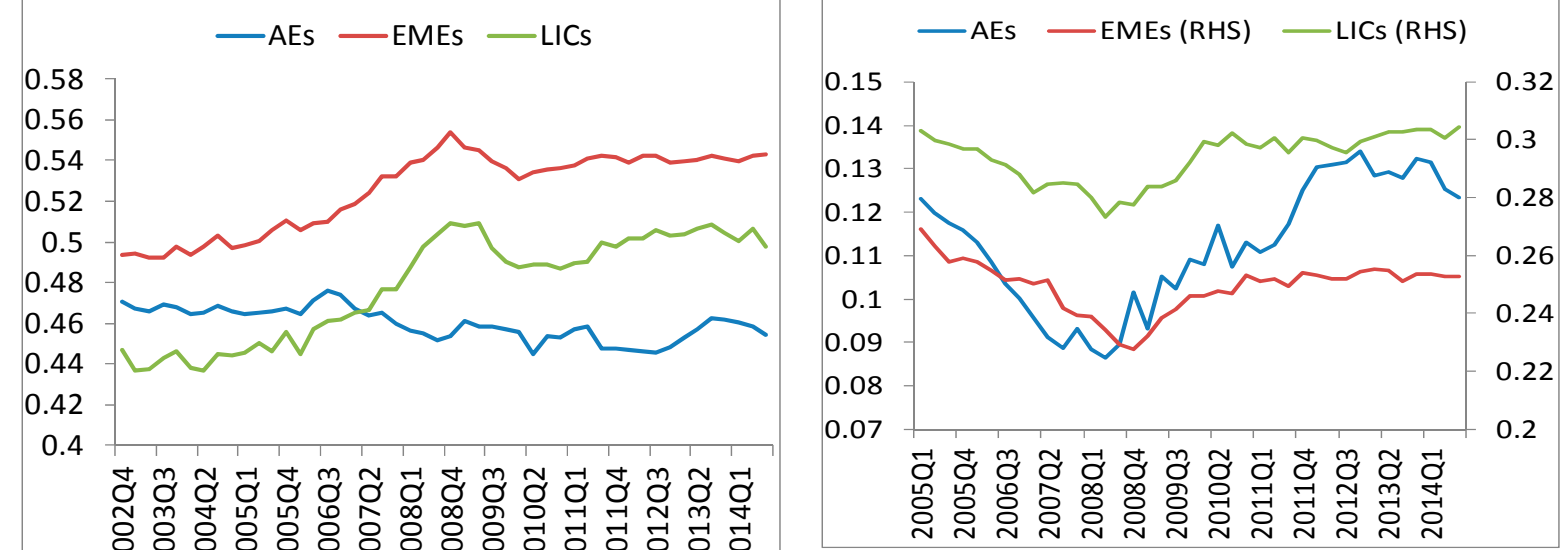

유 유 유육유 유유 유

Wholesale funding to total funding ratio

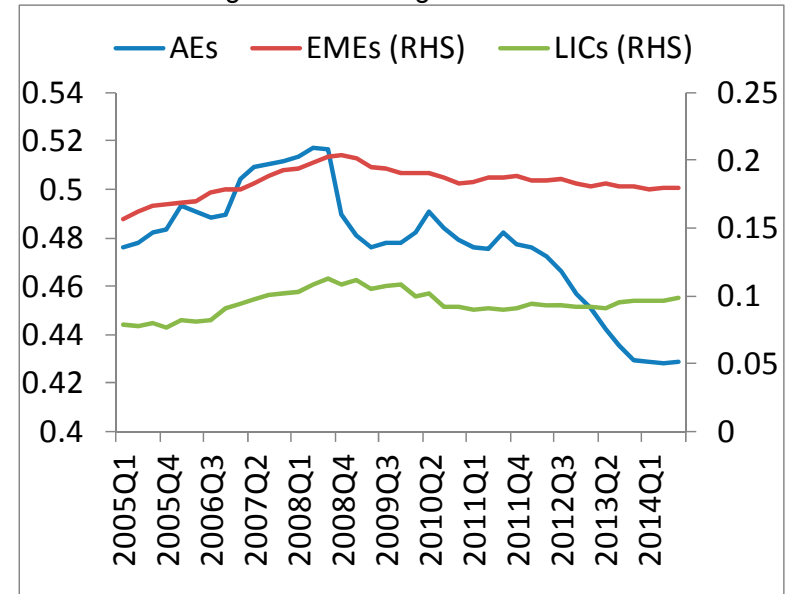

Funding from abroad to total funding ratio

Source: IMF SRF Data.

Note: Data for country groupings calculated as simple averages across countries. 


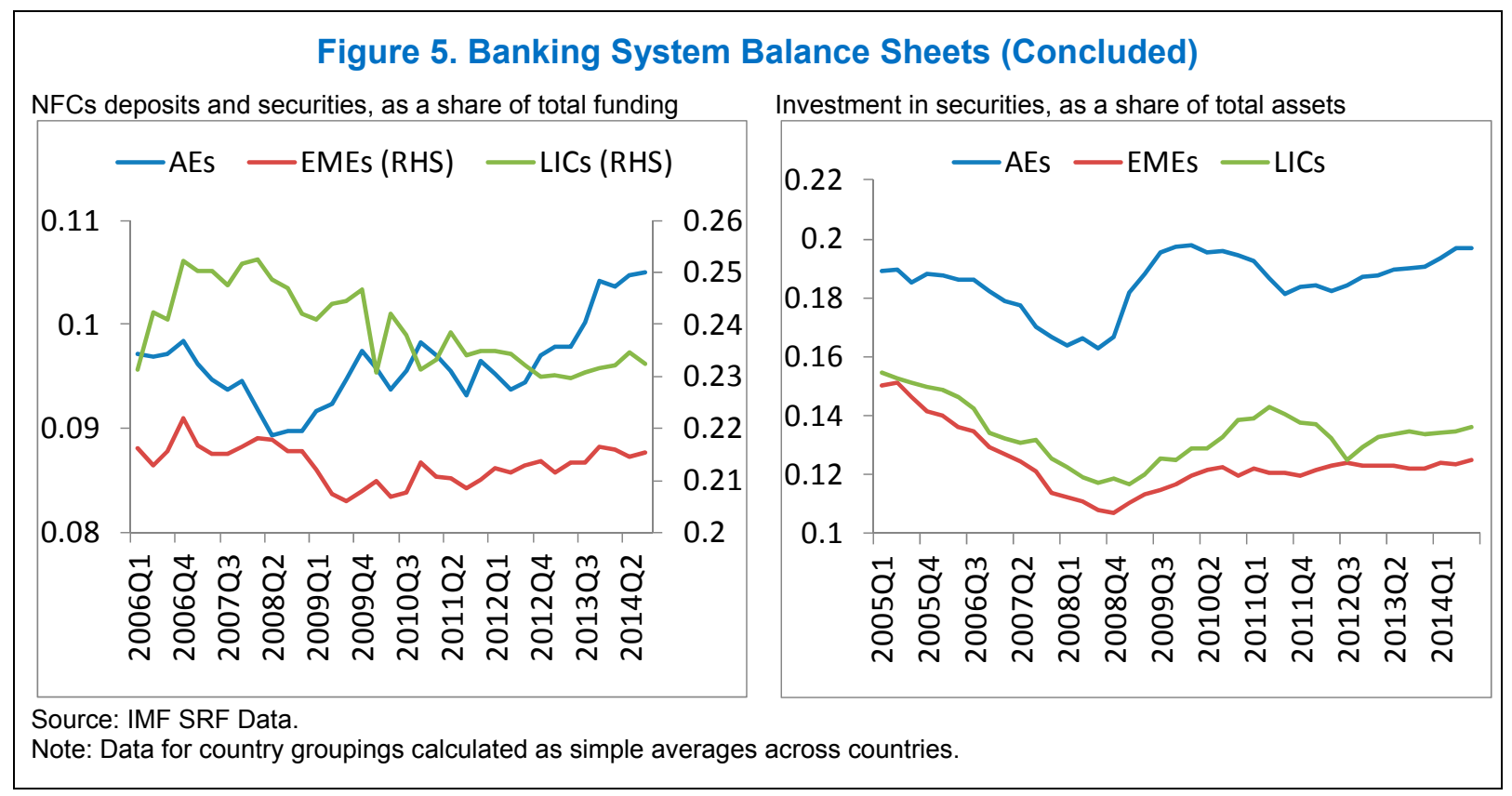

- In Turkey (Figure 6), expansionary domestic policies, accompanied by abundant global liquidity, led to an increased share of non-resident holdings in total funding of ODCs, and, as a result, a decreased reliance on stable funding sources (i.e., domestic deposit). The share of non-core liabilities has doubled since 2009, whereas equity funding did not expand. Turkey's financial sector was mildly impacted by the global financial crisis of 2008-09, while recent trends call for continued close monitoring to preserve the sector's resilience going forward. In light of these developments, Turkish authorities adopted prudential measures to improve banking system resilience, such as the reserve option mechanism and asymmetric increase of the reserve requirements for (i) foreign currency (FX) denominated deposits against local currency deposits, (ii) non-core FX denominated deposits against core FX denominated deposits, and (iii) non-core short term deposits against non-core long term deposits since the first quarter of 2015.

- The situation looks different in Brazil (Figure 6). Monetary tightening and capital control measures implemented in Brazil in response to the increased capital inflows seemed to have helped maintain the non-resident participation share of total ODC funding and reliance on non-core liabilities. At the same time, increased volatility and weaker growth prospects could be important factors behind the decreased share of domestic deposits. Continued expansion of credit calls for close monitoring, particularly as share of equity funding remains stable. 
Figure 6. Brazil vs. Turkey Financial Assets and Liabilities, 2005 to H1 2014

Share of deposits in total funding

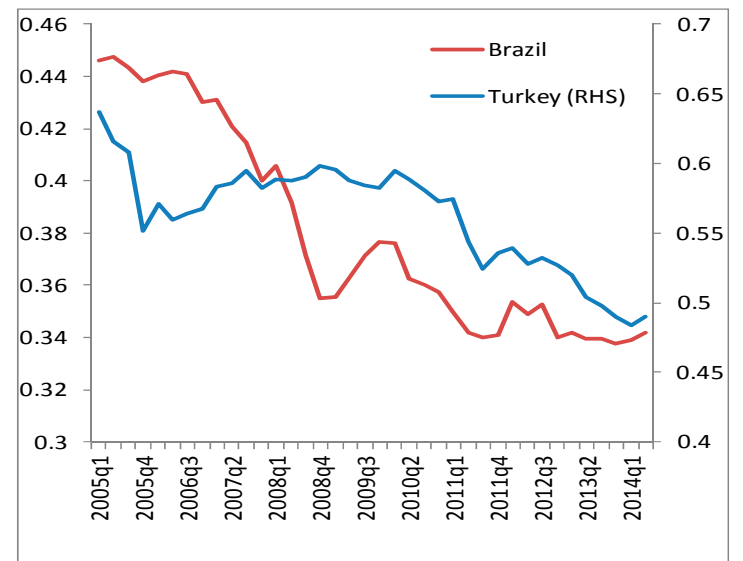

Share of noncore liabilities in total liabilities

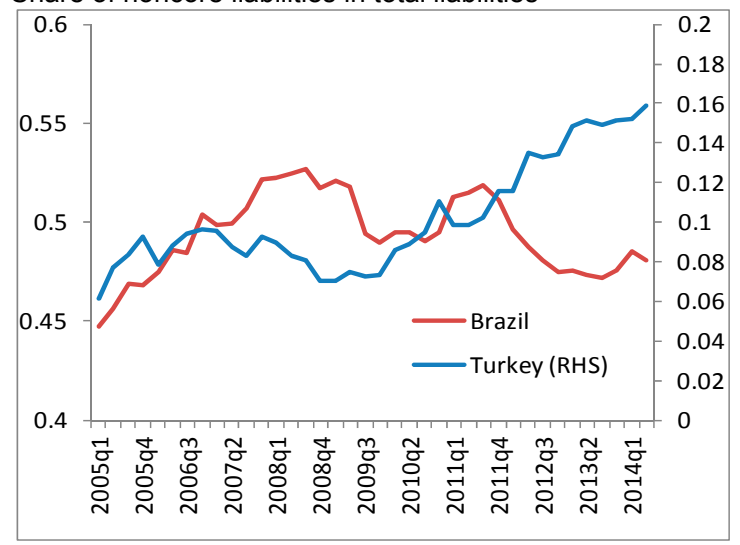

Share of private credit in total assets

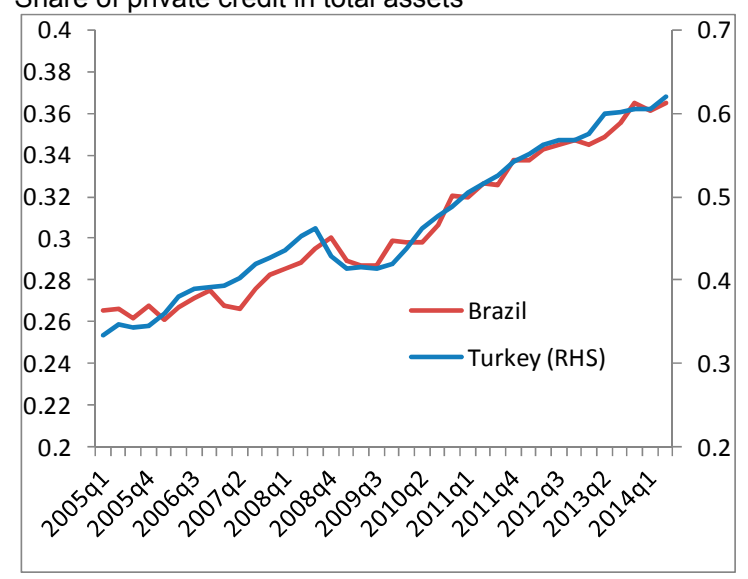

Source: IMF SRF Data.
Share of nonresidents in total funding
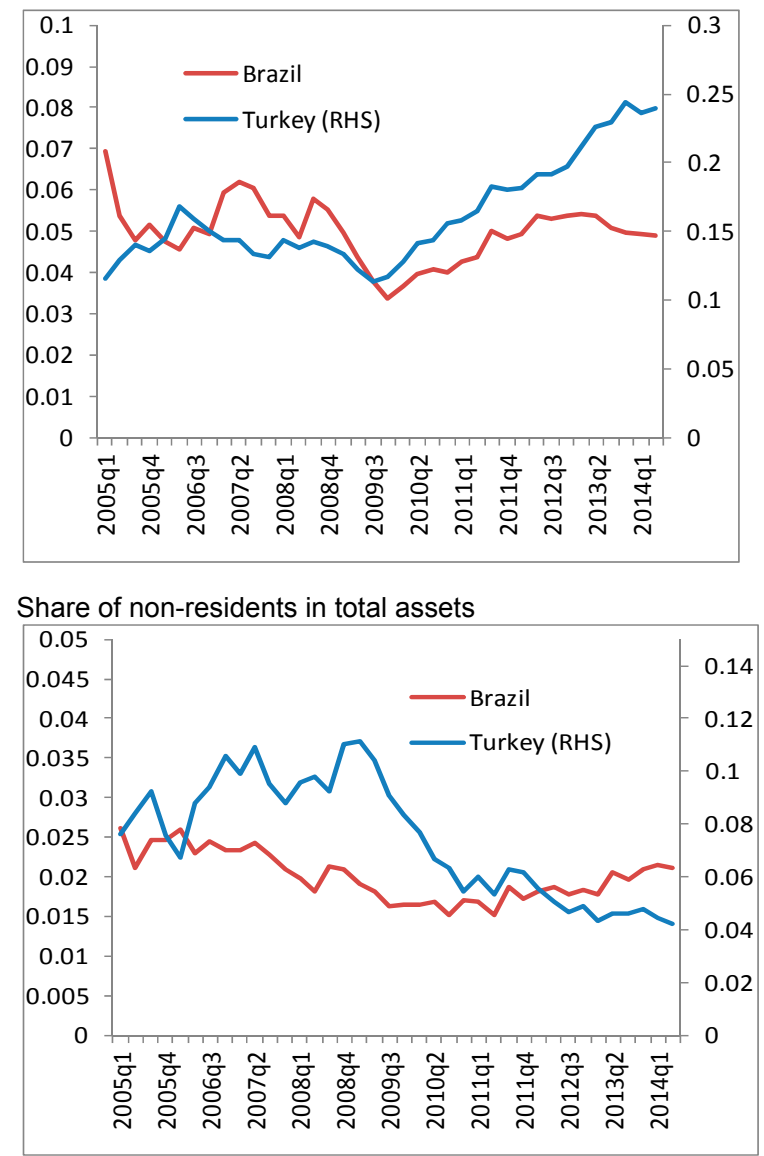

Share of equity in total funding

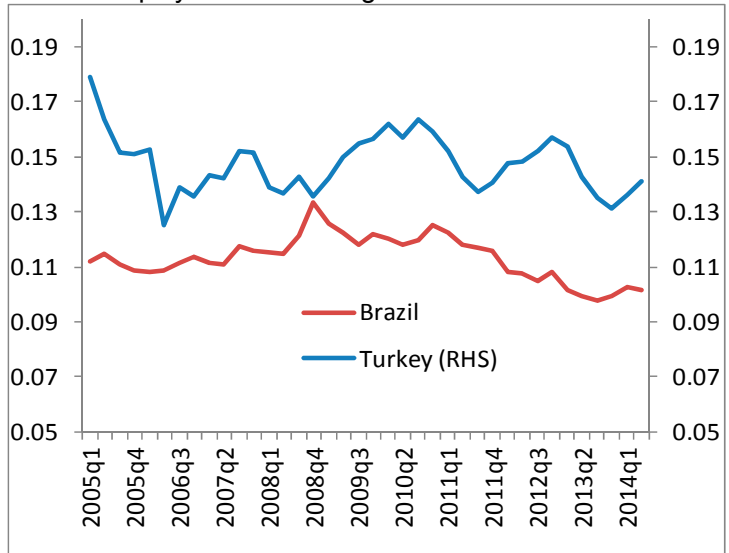


The detailed analysis of banking system balance sheets show that global liquidity and monetary conditions indeed associated with significant changes on EMEs and LICs balance sheets, and, as such, impacted liquidity, monetary conditions, and bank funding structures with rather diverging effects depending on a country's characteristics. While it is an important factor, domestic macro-financial policies matter for investors' differentiation among EMEs. Therefore, EME authorities should be cognizant of the need to cautiously monitor macro-financial vulnerabilities and fine-tune policies to adequately react to global challenges (and volatile capital flows). In the same vein, if the abundant global liquidity leads to reallocation of resources on banks' balance sheets and encourages loosening fiscal discipline, this might heighten the risks of policy mistakes. On the fiscal side, the room to maneuver could conceivably shrink due to increased public sector borrowing from abroad, in part as a result of search for yield in a low interest rate environment. As highlighted in the April 2015 Fiscal Monitor, debt ratios while generally moderate (about 42 percent of GDP) at present, are in many cases well above their pre-crisis levels and could constrain fiscal policy space in future (Figure 7). We would add that low oil prices add to fiscal pressures in commodity exporting countries.

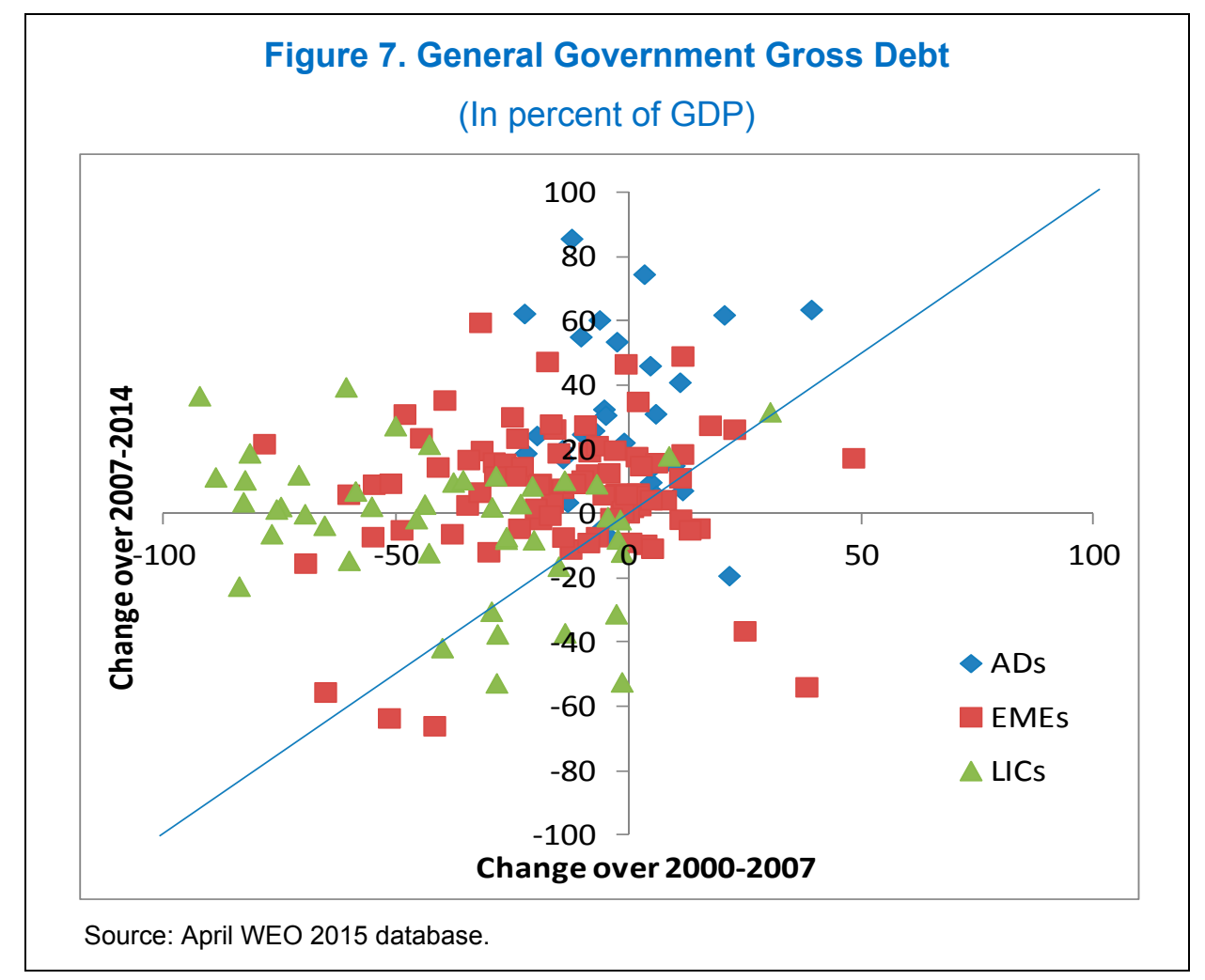




\section{EMPIRICAL ANALYSIS AND RESUlts}

\section{A. Empirical Specifications}

To conduct formal empirical analysis, we are guided by the following analytical framework. We define a time-series regression model (following Ahmed and Zlate (2013), Cerutti (2014), Chung et al. (2014) ) to assess the impact of QE/UMPMs on global liquidity measures:

$$
\begin{aligned}
& \Delta G L_{t}=\beta_{0}+\beta_{1} \cdot \Delta V I X_{t}+\beta_{2} \cdot \Delta G R G D G P_{t}+\beta_{3} \cdot G C P I_{t}+\beta_{4} \cdot \Delta I N T O F F_{t}+\beta_{5} \cdot \Delta R E E R_{-} U S D_{t}+ \\
& \Delta L T I R_{-} Q E_{t}^{S}+\varepsilon_{t},
\end{aligned}
$$

where:

$\Delta G L_{t}$ - the quarterly growth of global liquidity measured as quarterly growth rate in global money supply, NFC deposits, global domestic or cross-border credit, and global issuance of international securities at time $t$.

$\Delta V I X_{t}$ - the contemporaneous log difference in the VIX ${ }^{37}$ from the previous quarter at time $t$

$\triangle G R G D G P_{t}$-real global GDP growth at time $t$

$\triangle I N T O F F_{t}$ - U.S. banks' interoffice cross-border positions (one period percentage change) at time $t$;

$\mathrm{GCPI}_{t}$ —global CPI change, percent per annum, at time $t$;

$\triangle R E E R_{-} U S D_{t}$ - the quarterly log difference in real effective exchange rate for US, at time $t$; and

$\triangle L T I R_{-} Q E_{t}^{S}$ - instrumented changes in long-term bond yields that could be attributed to unconventional monetary policies in each of the $\mathrm{S} 4$ countries individually and the $\mathrm{S} 4$ as a whole at time $t$.

Following the approach suggested by Ahmed and Zlate (2013), first, we regress the change in long-term bond yields (in percentage points) on one quarter ahead change of stocks of nominal values of assets purchases by the concerned central bank converted to U.S. dollars and normalized by the S4 nominal GDP (in percentage points). To construct the variable, we

\footnotetext{
${ }^{37}$ For detail definition of the variables see Annex 1.
} 
subtract from the fitted value the estimated constant and error terms. ${ }^{38,39}$ This model is estimated for the period Q1:2002-Q2:2014, using a simple OLS method bootstrapped regressions with 1,000 replications, as well as the GLS method to account for serial autocorrelation in the residuals. All variables are checked to be stationary. The results are broadly robust to the choice of the estimation method. ${ }^{40}$

Next, we use cross-country panel regression analysis to analyze international spillovers of the S4 QE/UMPM programs on the liquidity and monetary conditions of individual country and country groupings. The baseline estimated model is the following:

$$
\Delta L_{c, t}=\beta_{c}+\beta_{1} \cdot \Delta V I X_{t}+\beta_{2} \cdot \Delta L T I R_{-} Q E_{t}^{S}+\beta_{3} \cdot \Delta I N T O F F_{t}+\text { controls }_{c, t}+\varepsilon_{c, t},
$$

where:

$\Delta L_{c, t}$ - the log difference of liquidity measured as broad money supply, NFC deposits, and issuance of securities (split by public, financial and non-financial sectors) for country $c$ at time $t$;

$\Delta V I X_{t}$ - the contemporaneous log difference in the VIX from the previous quarter at time $t$;

$\triangle I N T O F F_{t}$ — the log difference of the global banks' interoffice cross-border positions at time $t$;

$\triangle L T I R_{-} Q{ }_{t}^{s}$ - instrumented changes in long-term interest yields that could be attributed to unconventional monetary policies in each of the $\mathrm{S} 4$ countries individually and the $\mathrm{S} 4$ as a whole at time $t$;

controls $_{c, t}$-individual country real GDP growth, inflation, change in the real effective exchange rate (REER), the difference between domestic and global interest rate, current account to GDP ratio, growth of export, the Chinn-Ito index, change in banks' total assets, set of institutional and regulatory measures for country $c$ at time $t$; and

\footnotetext{
${ }^{38}$ See Annex 2 for a full description of the QE/UMPM variables.

${ }^{39}$ It is possible that the UMPMs, as identified, do not correctly measure the effects of individual UMPMs (i.e., coefficients of some countries' UMPMs may absorb the effects of other countries' UMPMs), considering the fact that different countries UMPMs were implemented sometimes in the same time periods. To test for possible misidentification we included S4 UMPM variables one by one to the model and estimated the coefficients (including splitting QE programs for the United States into two different variables) and then added remaining UMPMs in other countries (one-by-one and all together) to the model to check for the change in the coefficients, their significance and signs. The results confirm our main finding.

${ }^{40}$ To account for possible endogeneity, we use Bayesian vector auto-regression analysis (BVAR) with no restrictions on the variables order to estimate the basic model, and find that the results are not impacted.
} 
$\beta_{c}$ — country fixed effects; and

$\varepsilon_{c, t}$-residual term for country $c$ at time $t$.

The panel regression model is estimated for the period Q1:2002-Q2:2014 and includes country fixed effects and standard errors clustered at the country level.

The choice of the variables in models (1) and (2) is suggested by theoretical studies and based on previous empirical research on determinants of money supply or correlation between money supply and/or liquidity measures with real sector activities. One of the earliest studies that focused on the money stock was McKinnon (1982). More recent studies have used monetary aggregates and liquidity measures to analyze what drives global liquidity and how global liquidity is associated with capital flows and credit availability. ${ }^{41}$

As global control variables, we use the change in the VIX index (the stock option market implied volatility for the United States) to capture global economic and financial market volatility. To control the global economic cycle, we use the growth of the global real GDP. We use the U.S. term spread between the 10-year and three-month Treasury yields (or the U.S. Fed long-term interest rate) ${ }^{42}$ to capture the spillover effects from the United States to the rest of the world, as well as various constructed UMPM variables. ${ }^{43}$ We follow the approach suggested by Ahmed and Zlate (2013) and use changes in actual net asset purchases by the S4 central banks during Q1:2002-Q4:2013 as a dependent variable in the first stage regression model to isolate more directly the change in long-term yields that could be attributed to unconventional monetary policies in each of the S4 countries individually and the S4 as a whole. ${ }^{44}$ Additionally, we control for the developments in the global bank internal capital markets using BIS information on interoffice claims.

To control for individual country demand and risks characteristics, we use country specific control variables, such as (lagged) real GDP growth, inflation, change in REER, the spread between local and international (U.S. federal fund rate) policy interest rates, export growth,

\footnotetext{
${ }^{41}$ Bruno and Shin (2013), Cerruti, Claessens and Ratnovski (2014), Chung et al. (2012), Shin and Zhao (2013), and Chung et al. (2014).

${ }^{42}$ For the U.K. and Japan, we use the spread between 10-year and three-moth government bond yield; and for the euro area the spread between the 10 -year government bond yield and the main refinancing rate.

${ }^{43}$ See Appendix II for full description.

${ }^{44}$ Specifically, we first regress the annual change in long-term bond yield (in percentage points) on actual net asset purchases one quarter ahead (normalized by S4 nominal GDP). The one-quarter ahead value of asset purchases, rather than the contemporaneous value helps to deal with the announcements effect which precedes the actual purchases.
} 
current account in percent of GDP, change in total banks' assets, and a number of other country specific characteristics that define institutional and regulatory environment.

Model (2) estimated in the paper uses different country groupings based on income levels (advanced economies, and middle and low income countries), and includes and excludes the S4 countries from the sample (results are presented in Annex 3, Tables 3.2-3.7). One of the reasons to exclude $\mathrm{S} 4$ countries from the sample is to reduce spending and demand endogeneity and reverse causality issues from the $\mathrm{S} 4$ countries to the RoW, as the primary purpose of UMPMs is to influence domestic market assets prices and in this way stimulate S4 countries.

\section{B. Impact on Global Liquidity, Global Monetary Aggregates, and Cross-Border Credit}

To demonstrate how UMPMs impacted various global variables, we use the dataset identified in section A and estimate model (1). The main result of assessing whether UMPMs in the S4 had similar impact on global liquidity, global monetary aggregates and cross-border credit are the following (Annex 3, Table 3.1):

- There is a positive but not robustly significant impact (association) of S4 UMPMs on global liquidity measures, as defined by the global growth of broad money, measured as M2 (or alternative measure of global money supply), ${ }^{45}$ global NFC deposit growth, or global domestic credit growth. ${ }^{46}$

- There is a positive impact of total S4 UMPMs on international banks' crossborder (foreign and international) credit growth, and, in particular, extension of loans with longer maturity, when we control for global banks' inter-office lending. The results suggest no statistically significant impact of UMPMs on cross-border credit if we split the sample into banks, public sector, and nonbanks.

- There is a positive association between S4 UMPMs and international issuance of debt securities by non-S4 countries in FX.

The results show that banks and NFCs globally reduced their nominal spending and seem to repair their balance sheets after the crisis, confirming a similar result by Butt et al. (2012). Additionally, Butt, et al. (2014) find that QE in U.K. gave rise to deposits that are likely to be short-lived in a given bank ('flighty' deposits), and as such its effect on bank lending is

\footnotetext{
${ }^{45}$ See definition of the variables in Annex 1.

${ }^{46}$ When we include each UMPM into the regression individually or all of them jointly, the results for individual UMPM are inconclusive.
} 
diminished. Banks sold low-yield government debt to non-banks and thus non-bank deposits in the banking sectors declined. ${ }^{47}$ In addition, there has been substitution of bank credit by non-banks loans (such as, for example, trade credit), confirming observations from Chang et al. (2014). At the same time, there was a targeted impact on particular segments of financial markets-MBS, GSE in the United Sates, (B. Friedman, 2014) and banks in Japan seemed to be buying asset backed commercial papers (ABCP) to cure bank balance sheets (Iwata and Takenaka, 2012).

The differential nature of UMPM programs can have potentially countervailing effects on each other and on global liquidity. For example, the U.S. Fed was concentrating on the asset side of the balance sheet to support the financial intermediary function, while the BoJ was targeting the liability side to provide a buffer against funding liquidity by increasing private banks' excess reserve. The difference in policies is explained in part by the differences in financial systems - market-based system in the United States versus bank-based system in Japan. In addition, a positive effect of the QE programs in the United States might be reduced to a certain extent by the faster rate of new government bond issuance than the Fed's purchase of bonds. In comparison, we find similar mixed results as in the BIS/ECB research concerning the impact of the ECB UMPM programs. One of the conclusions here is that nonstandard monetary policy measures, while being instrumental in supporting financial intermediation and economic activity in the euro area, have had minimal impact on the euro area bank lending during 2010-13. Perhaps, the ongoing balance sheet repair of euro area banks has mitigated UMPM's impact. ${ }^{48}$

In addition, the results confirm conventional wisdom that there is a need to improve global banks' capital and solvency positions_-global banks interoffice claims are highly statistically significant and positively associated with global liquidity measures. Meanwhile, the appreciation of the dollar has a strong negative impact on global liquidity.

\section{International Spillovers of S4 UMPMs}

To analyze international spillovers of the S4 UMPM programs on the liquidity and monetary conditions of individual country and various country groups, we estimate model (2) (see Annex 3. Table 3.2-3.7). ${ }^{49}$

\footnotetext{
${ }^{47}$ While yields on government bonds went down significantly, they remain higher than interest paid on bank deposits, which partly explains non-banks interest in this product.

${ }^{48}$ Constancio (2014), Cour-Thimann and Winkler (2013), and BIS quarterly review $(2013,2014)$.

${ }^{49}$ In the Annex we present only the main results. The additional tables with robustness check are available on request.
} 
The main results of the cross-country panel regression model (2) are the following:

- In line with our results on global liquidity, we find positive significant impact (association) of UMPMs on broad money growth, growth of NFC deposits, and international issuance of debt securities. This result holds for broader measures of money supply defined as total holdings of ODCs' deposits and securities and is primarily driven by EMEs - the coefficient on UMPMs in advanced economies sample is insignificant. The significance also disappears when we add dummies for foreign bank presence.

- When we split total UMPM impact by country we find a statistically negative impact of U.S. and U.K. assets' purchases on monetary and liquidity conditions in EMEs and LICs. At the same time, U.S. QE has a significantly positive association with the growth rate of broad money in advanced economies. The introduction of QE in Japan has positive spillover to EMEs liquidity and monetary conditions and one of the possible channels is through increased Japanese banks foreign claims on EMEs. This result is robust in different samples and when we control for institutional variables. ${ }^{50}$ While there is a positive association between EA UMPMs with other countries' monetary and liquidity conditions, this result is not robust to the model and variable specifications.

- The results for NFCs deposit growth are similar and even more significant. United Kingdom QE program had significant negative impact on NFCs deposits growth globally. This negative impact was compensated by the positive spillovers from Japan QE and EA UMPMs. ${ }^{51}$ U.S. QE measures also seem to have positive association with the NFCs deposit growth in advanced economies.

- We find strong positive association between QE in the United Kingdom and issuance of non-financial sector securities globally and negative relationships between QE in Japan and issuance of NFC bonds in other countries. We also find positive impact of the EA UMPMs on global issuance of NFCs' securities, primarily driven by the impact on other advanced economies. These results are robust to different specifications. Additionally, there is no statistically significant association between the UMPMs and issuance of public sector or financial sector securities. ${ }^{52}$

\footnotetext{
${ }^{50}$ This result is supported by the conclusions of the April 2015, GFSR Chapter 2 on "International Banking After the Crisis: Increasingly Local and Safer?"

${ }^{51}$ Casiraghi et al. (2013) and Boeckx, Dossche and Peersman (2014) also find an evidence of the beneficial impact of the EA UMPMs on Italian and EA credit supply and money market conditions.

${ }^{52}$ Additional results are available on request.
} 
These results are largely driven by the EMEs. This is not surprising, as the data described above showed clear indications of increased debt and securities issuance and other capital flows into these countries. The capital inflows into EMEs were probably led by a search for higher yield by foreign investors, as well as "carry trade" by domestic NFCs, which borrowed in hard currencies abroad and parked some proceeds in local banks.

The results for advanced economies are mixed and generally less significant. At the same time, there is an indication that the $\mathrm{QE}$ in the United States had significant positive impact on advance countries' money growth and liquidity, while UMPM measures in EA are positively associated with the increase issuance of NFCs securities in advanced economies.

\section{CONCLUSIONS AND POLICY IMPLICATIONS}

Through a detailed descriptive and econometric analysis the results of this paper suggest that the impact on global liquidity, monetary conditions, and bank balance sheets from individual S4 UMPMs differ depending on the nature of each program, initial macro-economic conditions, and countries' policy response. The U.S. QE programs might dominate in impact due to its size and the relevance of the U.S. dollar as a global transaction currency.

In addition, while we find a positive impact of S4 UMPMs on global liquidity and money growth, the differential nature of these programs can potentially have countervailing effects on each other and on global liquidity. For example, the U.S. Fed was concentrating on the asset side of the balance sheet to support the financial intermediary function, while the BoJ was targeting the liability side to provide a buffer against funding liquidity by increasing private banks' excess reserves. The difference in policies explained in part by the differences in financial systems (market-based system in the United States versus bank-based system in Japan). Targeted assets purchases programs may have a potential positive impact on asset markets as they may prevent excessive swings in asset prices.

The S4 UMPM policies had a statistically significant impact on the EMEs' banks money supply and funding liquidity though their impact on bank balance sheets, NFCs deposits, and NFC securities issuance. The portfolio rebalancing channel of QE/UMPM policies has led to the redistribution and increased issuance of EMEs' debt and has increased the non-core liabilities in EME banking sectors.

The results also suggest that non-core liabilities of EME banks exhibit higher volatility than those of developed countries, making EMEs banking systems more vulnerable to the S4 monetary policy reversals and unwinding of the programs. At the same time, macro-

prudential regulation in EMEs may become less effective due to the increased significance of the non-banking sector as de facto "financial intermediary." 
Furthermore, UMPM programs have been accompanied by economic costs, since they seem to have led to the reallocation of resources on banks' balance sheets and possibly contributed to loosening fiscal discipline in EMEs. Therefore, close monitoring of macro-financial vulnerabilities in EMEs and undertaking debt sustainability analysis on a frequent basis may be prudent to head-off policy mistakes and to maintain financial stability. Finally, as monetary policy begins to normalize in the S4, RoW liquidity and monetary conditions might get tighter. As the "taper tantrum" episode of 2013 showed, ${ }^{53}$ simply signaling a change in future monetary policy can create a wave of extreme volatility in the markets, influencing RoW exchange rates, flows and asset prices. This suggests the need for better communication among central banks and with the financial markets in addition to strengthening of the global financial safety net.

A full assessment of the effects of the UMPMs can be made only after a complete return to a normalized monetary policy. Nonetheless, at this point, our analysis can help shed light on the potential impact of the UMPMs on global monetary and liquidity conditions.

${ }^{53}$ Sahay et al. (2014). 
AnNeX 1: DATA Description

\begin{tabular}{|c|c|c|}
\hline Variable & Definition & Data Source \\
\hline Global liquidity & $\begin{array}{l}\text { Measured as quarterly growth } \\
\text { rate in global money supply, } \\
\text { non-financial corporate (NFC) } \\
\text { deposits, global domestic or } \\
\text { cross-border credit, or global } \\
\text { issuance of international } \\
\text { securities. }\end{array}$ & IMF IFS, SRF, BIS \\
\hline $\begin{array}{l}\text { Broad money } \\
\text { growth }\end{array}$ & $\begin{array}{l}\text { Growth of broad money } \\
\text { liabilities. Global money supply } \\
\text { calculated by summing up broad } \\
\text { money liabilities for all countries } \\
\text { in our sample. }\end{array}$ & $\begin{array}{l}\text { Depository corporations survey 3SG for } \\
\text { IFS }\end{array}$ \\
\hline $\begin{array}{l}\text { NFC deposits } \\
\text { growth }\end{array}$ & $\begin{array}{l}\text { The sum of transferable and } \\
\text { other deposits of public and } \\
\text { other (private) non-financial } \\
\text { corporations to other depository } \\
\text { corporations (ODCs), included in } \\
\text { and excluded from broad money, } \\
\text { national and foreign currency. } \\
\text { Change over the period } \\
\text { in percent to the stock of NFC } \\
\text { deposits in a previous period }\end{array}$ & $\begin{array}{l}\text { Other Depository Corporations Survey 2SG } \\
\text { for the International Financial } \\
\text { statistics (IFS), IMF, as reported by the } \\
\text { country authorities }\end{array}$ \\
\hline $\begin{array}{l}\text { Real Effective } \\
\text { Exchange Rate }\end{array}$ & Real Effective Exchange Rate & Bank of International Settlements (BIS) \\
\hline VIX & $\begin{array}{l}\text { Chicago Board Options } \\
\text { exchange Market Volatility Index, } \\
\text { the implied volatility of S\&P } 500 \\
\text { index options; average }\end{array}$ & Bloomberg \\
\hline $\begin{array}{l}\text { Policy rate } \\
\text { differential }\end{array}$ & $\begin{array}{l}\text { Difference between domestic } \\
\text { rate and Fed funds rate }\end{array}$ & IMF IFS \\
\hline $\begin{array}{l}\text { Global banks } \\
\text { interoffice claims }\end{array}$ & $\begin{array}{l}\text { Growth in interoffice claims of } \\
\text { the BIS reporting banks }\end{array}$ & $\mathrm{BIS}$ \\
\hline GDP growth & Real GDP growth, annual & $\begin{array}{l}\text { National Accounts Database, STA/IMF, as } \\
\text { reported by country authorities }\end{array}$ \\
\hline Global GDP growth & Real GDP growth, annual & WEO \\
\hline Inflation & $\begin{array}{l}\text { Annual percentage change of } \\
\text { the CPI, end of period }\end{array}$ & $\begin{array}{l}\text { National accounts Database, STA/IMF, as } \\
\text { reported by country authorities }\end{array}$ \\
\hline $\begin{array}{l}\text { Global NFC } \\
\text { deposits }\end{array}$ & $\begin{array}{l}\text { Sum of the non-financial } \\
\text { corporate deposits in U.S. } \\
\text { dollars (EUR, JPY) }\end{array}$ & $\begin{array}{l}\text { Other Depository Corporations Survey 2SG } \\
\text { for the International Financial } \\
\text { statistics (IFS), IMF, as reported by the } \\
\text { country authorities }\end{array}$ \\
\hline $\begin{array}{l}\text { Current Account to } \\
\text { GDP }\end{array}$ & $\begin{array}{l}\text { BoP data on current account } \\
\text { divided by nominal GDP in } \\
\text { U.S. dollars }\end{array}$ & IMF IFS, BoP \\
\hline
\end{tabular}




\begin{tabular}{|l|l|l|}
\hline Export growth & $\begin{array}{l}\text { Export of goods and non-factor } \\
\text { services (in U.S. dollars) }\end{array}$ & $\begin{array}{l}\text { Balance of Payments and international } \\
\text { Investment Position (compiled by the sixth } \\
\text { edition methodology, BPM6), Statistics } \\
\text { Department (STA), IMF, as reported by } \\
\text { country authorities }\end{array}$ \\
\hline $\begin{array}{l}\text { Fixed exchange } \\
\text { rate regime dummy }\end{array}$ & $\begin{array}{l}\text { Equals one if country has fixed } \\
\text { exchange rate, zero otherwise. }\end{array}$ & Ilzetzki, Reinhart, and Rogoff (2011) \\
\hline $\begin{array}{l}\text { Foreign ownership } \\
\text { dummy }\end{array}$ & $\begin{array}{l}\text { Whether foreign banks may own } \\
\text { domestic banks and whether } \\
\text { foreign banks may enter a } \\
\text { country's banking industry. } \\
\text { Equals one if there is no } \\
\text { restrictions, and zero otherwise. }\end{array}$ & World Bank surveys on bank regulation \\
\hline $\begin{array}{l}\text { Capital account } \\
\text { openness }\end{array}$ & $\begin{array}{l}\text { Index measuring a country's } \\
\text { degree of capital account } \\
\text { openness }\end{array}$ & $\begin{array}{l}\text { The Chinn-Ito Index, initially introduced in } \\
\text { Chinn and Ito (2006), } \\
\text { http://web.pdx.edu/ ito/Chinn- } \\
\text { Ito_website.htm }\end{array}$ \\
\hline $\begin{array}{l}\text { U.S. long-term } \\
\text { interest rate }\end{array}$ & 10 year U.S. Treasury yield & IMF IFS \\
\hline $\begin{array}{l}\text { U.K. long-term } \\
\text { interest rate }\end{array}$ & $\begin{array}{l}10 \text { year U.K. government } \\
\text { securities yield }\end{array}$ & IMF IFS \\
\hline $\begin{array}{l}\text { Japan long-term } \\
\text { interest rate }\end{array}$ & 10 year Japan Treasury yield & IMF IFS \\
\hline $\begin{array}{l}\text { ECB long-term } \\
\text { interest rate }\end{array}$ & 10 year EA AAA Sovereign yield & IMF IFS \\
\hline
\end{tabular}




\section{ANNEX 2: DEFINITION OF THE UMPM VARIABLES}

For the purpose of this research we collected the following information on asset purchases programs and UMPMs by BoE, BoJ, ECB, and the U.S. Fed:

\section{The United States}

For U.S. QE measure Fed's data on stock of agency—and GSE-backed securities' assets are used. During first phase of QE Fed buys US\$1.24 trillion in mortgage securities. On the 27 of August 2014, Ben Bernanke, the Chairman of the Federal Reserve at the time, gave a speech in which he set a stage for second and third phases of QE. During second phase of QE Fed buys US\$600 billion in the U.S. treasury securities. From September 9, 2011, until December 31, 2012, Fed engaged in the co-called "Operation Twist" transactions. During the third phase of QE, Fed bought US\$40 billion a month in mortgage securities (to infinity and beyond), and starting from 2013 Fed has been buying additional US $\$ 45$ billion a month in the U.S. Treasuries until unemployment rate falls to 6.5 percent. From December 2013, Fed officially announced tapering of QE. The purchase of the U.S. Treasury securities are referred as the first U.S. QE program, and the purchases of agency debt plus mortgagebacked securities are referred to as the second QE program.

\section{The United Kingdom}

In the United Kingdom, the principal element of the unconventional measures was the policy of asset purchases financed by central bank money, so-called quantitative easing (QE). In January 2009, the Chancellor of the Exchequer authorized the BoE to set up an Asset Purchase Facility (APF) to buy high-quality assets financed by the issue of Treasury bills and the DMO's cash management operations. ${ }^{1}$ When assets are purchased from non-banks (either directly or indirectly via intermediate transactions), the banking sector gains both new reserves at the Bank of England and a corresponding increase in customer deposits. Between March 2009 and May 2012, the BoE purchased $£ 325$ billion worth of such asset. Since then, the BoE has expanded its APF by a further $£ 50$ billion. Weekly outstanding amounts of BoE assets were used to calculate the net actual purchases. The Bank also pursued a number of activities targeted to improve the functioning of specific financial markets, such as purchases of high-quality commercial paper and corporate bonds. The scale of these operations was much less than for the gilt purchases, consistent with the Bank acting as a backstop purchaser/seller with the intention of improving market functioning.

\footnotetext{
${ }^{1}$ For more information see http://www.bankofengland.co.uk/markets/Pages/apf/default.aspx and Joyce et al. (2011).
} 


\section{Japan}

Japan announced its QE1 in March 2001. ${ }^{2}$ The Bank increased the amount of its outright purchase of long-term government bonds from 400 billion yen per month, in cases where it was considered necessary for providing liquidity smoothly. The outright purchases were subject to the limitation that the outstanding amount of long-term government bonds effectively held by the Bank were kept below the outstanding balance of banknotes issued. The Assets Purchases Program (APP) was first introduced in October 2010 to promote economic growth and price stability. On October 5, 2010, the BoJ purchased JPY5 trillion in assets. In March, August, and October 2011, the BoJ increased the size of the APP by JPY5 trillion to JPY20 trillion to facilitate purchases of Japan government bonds (JGBs). This, along with the JPY35 trillion assigned to the fixed-rate funds-supplying operation, puts the APP at JPY55 trillion. The BOJ's APP also covers private sector financial assets, including commercial paper, corporate bonds, exchange-traded funds (ETFs), and real estate investment trusts (REITs) in addition to government securities. In February and April 2012, the BoJ purchased additional JPY20 trillion in assets. In July 2012, the BoJ conducted another purchase of JPY5 trillion. During September, October, and December 2012, the BoJ purchased JPY5 trillion in the JGB and JPY5 trillion in Treasury bills per month. In September 2013, the BoJ has expanded APP by JPY10 trillion, increasing overall size of the stimulus program to JPY80 trillion.

\section{ECB}

The ECB's UMPMs up to Q2 2014 are well described on the ECB website and in the ECB Monthly Bulletin. ${ }^{3}$

\section{Definition of the UMPM Variables}

We use changes in net asset purchases by the S4 central banks during Q1:2002-Q4:2013 as an independent variable to isolate more directly the change in long-term yields that could be attributed to unconventional monetary policies in each of the S4 countries individually and the S4 as a whole. In this we follow the approach suggested by Ahmed and Zlate (2013). First, we regress the change in long-term bond yields (in percentage points) on one quarter ahead change of stocks of nominal values of assets purchases by the concerned central bank converted to U.S. dollars and normalized by the S4 nominal GDP (in percentage points). To construct the variable, we subtract from the fitted value the estimated constant and error terms. In the first-stage regression (see below equation (3)), the coefficients on the changes in

\footnotetext{
${ }^{2}$ https://www.boj.or.jp/en/announcements/release_2001/k010319a.htm

${ }^{3}$ For more details see the Annex on Chronology of monetary policy measures of the Eurosystem, published up to December 2014 in the ECB Monthly Bulletin (www.ecb.int).
} 
UMPMs is negative and statistically significant at the 1 percent level, with about 20 to 40 percent of the variation in yields explained by implemented UMPMs over the period analyzed in the United States, the United Kingdom, and Japan. The UMPM measures in the euro area showed no statistically significant impact on the compression of the euro area longterm yields over the period. To construct the total S4 UMPM measure we use the change in the U.S. long-term bond yield (as a proxy for global interest rate) and regress it on one quarter ahead change in actual stocks of assets purchases by the S4 central banks (normalized by the S4 nominal GDP).

$$
\Delta L T_{-} I R_{c, t}=\beta_{c}+\beta_{1} \cdot \Delta U M P M_{-} G D P_{c, t+1}+\varepsilon_{c, t}
$$

\begin{tabular}{|c|c|c|c|c|c|c|c|}
\hline \multicolumn{8}{|c|}{$\begin{array}{l}\text { Table 2.1. Correlations between UMPMs in S4 } \\
\text { (Changes in assets purchases in percent of S4 GDP) }\end{array}$} \\
\hline & |US LSAP MBS\&GSE & US LSAP Treasuries & UK & Japan & ECB LTRO & ECB SMP & ЕСВ СВРP $1 \& 2$ \\
\hline US LSAP MBS\&GSE & 1.00 & & & & & & \\
\hline US LSAP Treasuries & 0.17 & 1.00 & & & & & \\
\hline UK & 0.50 & 0.23 & 1.00 & & & & \\
\hline Japan & 0.15 & 0.30 & 0.31 & 1.00 & & & \\
\hline ECB LTRO & 0.00 & -0.05 & 0.50 & 0.03 & 1.00 & & \\
\hline ECB SMP & -0.20 & 0.35 & 0.20 & 0.16 & 0.07 & 1.00 & \\
\hline ЕСВ СВРP $1 \& 2$ & 0.48 & 0.09 & 0.41 & 0.02 & -0.07 & 0.23 & 1.00 \\
\hline
\end{tabular}


Table 2.2. Summary Statistics for Two Samples

(Before 2002:Q1-2008:Q2 and after 2008:Q3-2013:Q3 the GFC)

\begin{tabular}{|c|c|c|c|c|c|c|c|c|c|c|c|c|}
\hline \multirow[b]{2}{*}{ Variable } & \multicolumn{6}{|c|}{ Before crisis } & \multicolumn{6}{|c|}{ After crisis } \\
\hline & Obs & Mean & Median & Std. Dev. & Min & Max & Obs & Mean & Median & Std. Dev. & Min & Max \\
\hline (change in logarithm quarter-on-quarter) & & & & & & & & & & & & \\
\hline US slope of yield curve, percent & 34 & 1.07 & 0.98 & 1.51 & -1.13 & 3.30 & 21 & 2.11 & 2.13 & 0.84 & 0.53 & 3.46 \\
\hline US long term IR, percent & 34 & 4.65 & 4.59 & 0.67 & 3.62 & 6.48 & 21 & 2.76 & 2.79 & 0.73 & 1.64 & 3.86 \\
\hline CBOE VIX growth, pp & 33 & -0.30 & -1.47 & 18.86 & -33.53 & 49.10 & 21 & -1.75 & -7.40 & 30.38 & -42.49 & 89.69 \\
\hline Global GDP growth & 33 & $0.9 \%$ & $1.4 \%$ & $1.8 \%$ & $-2.7 \%$ & $3.5 \%$ & 19 & $0.5 \%$ & $1.0 \%$ & $2.5 \%$ & $-5.0 \%$ & $3.5 \%$ \\
\hline Global Inflation, annualized level & 34 & $3.9 \%$ & $3.7 \%$ & $0.7 \%$ & $3.1 \%$ & $6.3 \%$ & 21 & $3.6 \%$ & $3.4 \%$ & $1.1 \%$ & $1.3 \%$ & $6.8 \%$ \\
\hline Global broad money growth, SRF reporters (USD) & 33 & $2.3 \%$ & $2.1 \%$ & $3.1 \%$ & $-7.1 \%$ & $7.6 \%$ & 21 & $0.3 \%$ & $0.7 \%$ & $3.1 \%$ & $-5.2 \%$ & $6.5 \%$ \\
\hline Global broad money growth, SRF reporters (EUR) & 33 & $0.6 \%$ & $0.8 \%$ & $2.4 \%$ & $-5.9 \%$ & $6.2 \%$ & 21 & $1.1 \%$ & $0.7 \%$ & $3.5 \%$ & $-4.2 \%$ & $7.6 \%$ \\
\hline Global broad money growth, SRF reporters (JPY) & 33 & $2.2 \%$ & $2.2 \%$ & $4.0 \%$ & $-6.1 \%$ & $13.5 \%$ & 21 & $-0.1 \%$ & $0.6 \%$ & $5.6 \%$ & $-12.1 \%$ & $10.8 \%$ \\
\hline Global broad money growth, all countries (USD) & 33 & $2.6 \%$ & $2.3 \%$ & $2.8 \%$ & $-4.9 \%$ & $7.4 \%$ & 21 & $1.2 \%$ & $1.9 \%$ & $2.5 \%$ & $-3.2 \%$ & $6.2 \%$ \\
\hline Global broad money growth, all countries (EUR) & 33 & $0.9 \%$ & $0.9 \%$ & $2.6 \%$ & $-6.3 \%$ & $6.6 \%$ & 21 & $1.9 \%$ & $1.5 \%$ & $3.7 \%$ & $-4.4 \%$ & $8.6 \%$ \\
\hline Global broad money growth, all countries (JPY) & 33 & $2.4 \%$ & $2.4 \%$ & $3.8 \%$ & $-6.0 \%$ & $12.6 \%$ & 21 & $0.8 \%$ & $0.6 \%$ & $5.7 \%$ & $-11.8 \%$ & $11.8 \%$ \\
\hline Global NFC deposits growth (USD) & 29 & $2.9 \%$ & $3.0 \%$ & $2.9 \%$ & $-3.5 \%$ & $9.1 \%$ & 20 & $0.7 \%$ & $-0.2 \%$ & $4.0 \%$ & $-6.9 \%$ & $8.6 \%$ \\
\hline Global NFC deposits growth (EUR) & 29 & $0.9 \%$ & $1.2 \%$ & $3.4 \%$ & $-8.1 \%$ & $6.4 \%$ & 20 & $1.6 \%$ & $1.7 \%$ & $3.3 \%$ & $-4.1 \%$ & $8.1 \%$ \\
\hline Global NFC deposits growth (JPY) & 29 & $2.4 \%$ & $2.5 \%$ & $3.4 \%$ & $-6.5 \%$ & $8.2 \%$ & 20 & $0.3 \%$ & $1.7 \%$ & $6.5 \%$ & $-14.7 \%$ & $10.7 \%$ \\
\hline Global NFC deposits growth, incl. China (USD) & 29 & $3.4 \%$ & $3.2 \%$ & $2.5 \%$ & $-1.2 \%$ & $8.4 \%$ & 20 & $2.2 \%$ & $1.8 \%$ & $2.7 \%$ & $-2.9 \%$ & $7.2 \%$ \\
\hline Global NFC deposits growth, incl. China (EUR) & 29 & $1.4 \%$ & $1.6 \%$ & $3.4 \%$ & $-7.6 \%$ & $7.2 \%$ & 20 & $3.1 \%$ & $3.1 \%$ & $3.8 \%$ & $-3.4 \%$ & $11.0 \%$ \\
\hline Global NFC deposits growth, incl. China (JPY) & 29 & $2.9 \%$ & $3.1 \%$ & $3.6 \%$ & $-6.4 \%$ & $9.5 \%$ & 20 & $1.8 \%$ & $1.9 \%$ & $6.3 \%$ & $-13.8 \%$ & $12.6 \%$ \\
\hline Global domestic credit growth & 33 & $1.6 \%$ & $1.5 \%$ & $0.5 \%$ & $0.6 \%$ & $3.3 \%$ & 21 & $1.4 \%$ & $1.4 \%$ & $0.5 \%$ & $1.0 \%$ & $3.2 \%$ \\
\hline Global cross border credit growth & 33 & $2.4 \%$ & $2.1 \%$ & $1.9 \%$ & $-1.9 \%$ & $6.6 \%$ & 21 & $-0.5 \%$ & $-0.2 \%$ & $2.2 \%$ & $-7.1 \%$ & $3.2 \%$ \\
\hline Consolidated foreign claims of BIS reporting banks & 33 & $3.8 \%$ & $3.7 \%$ & $3.5 \%$ & $-2.0 \%$ & $10.9 \%$ & 21 & $-0.7 \%$ & $-0.7 \%$ & $4.3 \%$ & $-11.4 \%$ & $7.2 \%$ \\
\hline Consolidated international claims of BIS reporting banks & 33 & $3.5 \%$ & $3.4 \%$ & $3.8 \%$ & $-3.7 \%$ & $11.4 \%$ & 21 & $-1.0 \%$ & $-1.1 \%$ & $4.7 \%$ & $-11.4 \%$ & $8.6 \%$ \\
\hline Up to and including 1 year & 33 & $3.4 \%$ & $3.3 \%$ & $4.9 \%$ & $-7.0 \%$ & $14.7 \%$ & 21 & $-1.1 \%$ & $-0.6 \%$ & $5.9 \%$ & $-17.3 \%$ & $9.1 \%$ \\
\hline Longer than 1 year & 33 & $3.7 \%$ & $3.6 \%$ & $3.3 \%$ & $-3.2 \%$ & $9.8 \%$ & 21 & $-0.9 \%$ & $-2.0 \%$ & $4.2 \%$ & $-7.1 \%$ & $8.1 \%$ \\
\hline on banks & 33 & $3.4 \%$ & $3.9 \%$ & $4.8 \%$ & $-5.0 \%$ & $17.7 \%$ & 21 & $-1.8 \%$ & $-1.4 \%$ & $5.5 \%$ & $-13.2 \%$ & $10.5 \%$ \\
\hline on public sector & 33 & $3.1 \%$ & $1.9 \%$ & $4.9 \%$ & $-5.1 \%$ & $20.6 \%$ & 21 & $0.7 \%$ & $1.4 \%$ & $6.2 \%$ & $-8.9 \%$ & $9.7 \%$ \\
\hline on non-banks & 33 & $4.0 \%$ & $4.2 \%$ & $3.8 \%$ & $-4.7 \%$ & $12.0 \%$ & 21 & $-0.7 \%$ & $-0.7 \%$ & $4.2 \%$ & $-11.5 \%$ & $6.2 \%$ \\
\hline Local currency claims on local residents & 33 & $4.4 \%$ & $3.9 \%$ & $3.7 \%$ & $-0.6 \%$ & $15.0 \%$ & 21 & $-0.2 \%$ & $-0.6 \%$ & $3.9 \%$ & $-11.3 \%$ & $6.3 \%$ \\
\hline $\begin{array}{l}\text { Local currency liabilities to local residents } \\
\text { Consolidated foreign claims of BIS reporting banks, }\end{array}$ & 33 & $4.3 \%$ & $2.7 \%$ & $4.7 \%$ & $-2.6 \%$ & $14.9 \%$ & 21 & $-0.6 \%$ & $-0.2 \%$ & $4.3 \%$ & $-14.0 \%$ & $5.0 \%$ \\
\hline inlcuding risk transfer & 33 & $3.8 \%$ & $3.6 \%$ & $3.6 \%$ & $-2.3 \%$ & $11.6 \%$ & 21 & $-0.7 \%$ & $-0.7 \%$ & $4.1 \%$ & $-11.6 \%$ & $5.7 \%$ \\
\hline International debt securities growth & 33 & $4.4 \%$ & $4.2 \%$ & $2.4 \%$ & $-0.7 \%$ & $10.2 \%$ & 21 & $0.5 \%$ & $-0.1 \%$ & $3.8 \%$ & $-5.5 \%$ & $7.8 \%$ \\
\hline $\begin{array}{l}\text { Net issuance of international debt securities (normalised } \\
\text { by the stock in pervious period) }\end{array}$ & 33 & $3.7 \%$ & $3.7 \%$ & $1.3 \%$ & $1.6 \%$ & $6.7 \%$ & 21 & $0.9 \%$ & $0.7 \%$ & $0.8 \%$ & $-0.3 \%$ & $2.7 \%$ \\
\hline
\end{tabular}




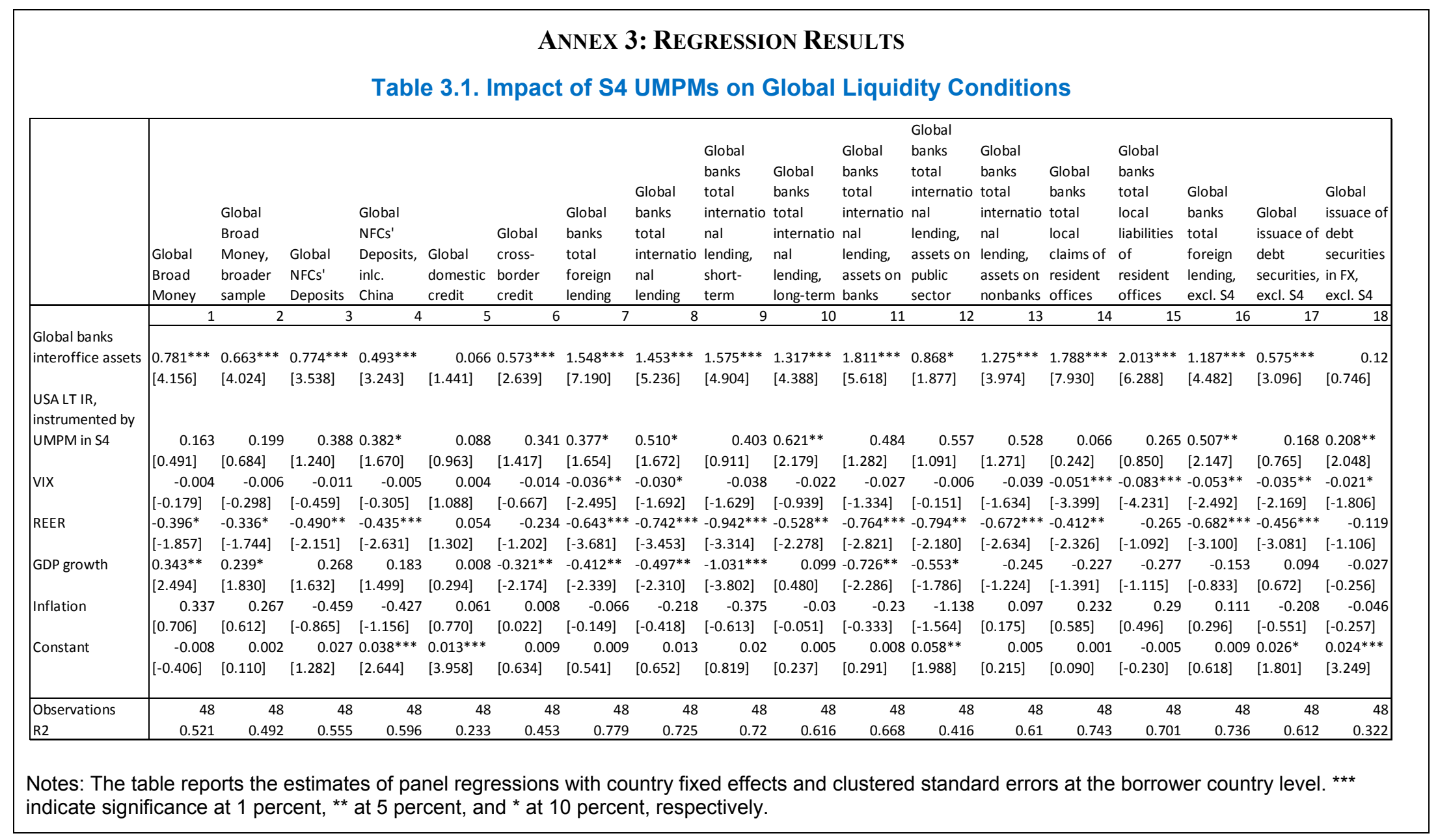


Table 3.2. Impact of UMPM Programs on Broad Money Growth

(Total UMPM)

\begin{tabular}{|c|c|c|c|c|c|c|c|c|}
\hline & \multicolumn{8}{|c|}{ Broad money growth, SRF reporters (USD) } \\
\hline & \multirow[b]{2}{*}{ All } & \multicolumn{7}{|c|}{$\mathrm{AE}$, excl. } \\
\hline & & Excl. S4 & Excl. S4 & Excl. S4 & S4 & $\mathrm{AE}$ & EME & Excl. S4 \\
\hline \multirow[t]{2}{*}{ Global banks interoffice claims } & $0.656 * * *$ & $0.655^{* * *}$ & $0.662 * * *$ & $0.682 * * *$ & $0.990 * * *$ & $0.942 * * *$ & $0.628 * * *$ & $0.660 * * *$ \\
\hline & [9.619] & {$[9.380]$} & [9.655] & [9.244] & {$[5.869]$} & [6.178] & [7.551] & [9.554] \\
\hline \multicolumn{9}{|l|}{ USA LT IR, instrumented by the } \\
\hline \multirow[t]{2}{*}{ UMPM } & $0.297 * * *$ & $0.305^{* * *}$ & $0.294 * * *$ & $0.318^{* * *}$ & $0.215^{* *}$ & $0.208^{* *}$ & $0.379 * * *$ & 0.113 \\
\hline & [4.909] & [4.924] & [4.890] & [5.313] & {$[2.425]$} & {$[2.692]$} & [4.304] & [0.914] \\
\hline \multirow[t]{2}{*}{ Change in VIX } & $-0.086 * * *$ & $-0.089 * * *$ & $-0.091 * * *$ & $-0.088 * * *$ & $-0.110 * * *$ & $-0.096 * * *$ & $-0.091 * * *$ & $-0.089 * * *$ \\
\hline & {$[-7.671]$} & {$[-8.023]$} & {$[-8.379]$} & {$[-8.016]$} & {$[-4.051]$} & {$[-3.496]$} & {$[-6.476]$} & {$[-8.078]$} \\
\hline \multirow[t]{2}{*}{ Change in REER } & $-0.057 * * *$ & $-0.055^{* *}$ & $-0.049 * *$ & $-0.049 * *$ & -0.033 & -0.059 & $-0.072 * *$ & $-0.056 * *$ \\
\hline & {$[-2.628]$} & {$[-2.504]$} & {$[-2.368]$} & {$[-2.321]$} & {$[-0.714]$} & {$[-1.357]$} & {$[-2.164]$} & {$[-2.550]$} \\
\hline \multirow[t]{2}{*}{ GDP growth } & $0.065^{* *}$ & $0.065^{* *}$ & $0.078 * *$ & $0.086^{*}$ & $0.095^{* * *}$ & $0.097 * * *$ & $0.065^{* *}$ & $0.065^{* *}$ \\
\hline & {$[2.526]$} & {$[2.516]$} & [2.432] & {$[1.975]$} & [2.937] & [3.019] & {$[2.185]$} & [2.509] \\
\hline \multirow[t]{2}{*}{ Inflation } & $0.055^{*}$ & $0.055^{*}$ & $0.088 * * *$ & $0.053^{*}$ & $0.187^{* * *}$ & $0.176^{* * *}$ & $0.078^{*}$ & $0.057^{*}$ \\
\hline & [1.852] & [1.845] & [3.627] & [1.837] & [3.180] & [3.136] & [1.991] & [1.941] \\
\hline \multirow[t]{2}{*}{ Policy rate differentional } & -0.089 & -0.093 & -0.097 & -0.1 & $0.637 * *$ & $0.725 * * *$ & $-0.173 * *$ & -0.096 \\
\hline & {$[-1.046]$} & {$[-1.113]$} & {$[-1.305]$} & {$[-1.197]$} & {$[2.652]$} & [3.061] & {$[-2.511]$} & {$[-1.126]$} \\
\hline \multirow[t]{2}{*}{ Capital Account Openess } & -0.001 & -0.001 & -0.001 & 0 & 0.012 & 0.012 & -0.002 & -0.001 \\
\hline & {$[-0.167]$} & {$[-0.169]$} & {$[-0.938]$} & [0.128] & [0.923] & [0.927] & {$[-0.647]$} & {$[-0.171]$} \\
\hline \multirow[t]{2}{*}{ Export growth } & $0.017 * *$ & $0.017 * *$ & $0.021 * * *$ & $0.018 * *$ & 0.013 & 0.012 & 0.018 & $0.017^{* *}$ \\
\hline & {$[2.182]$} & {$[2.208]$} & [2.663] & [2.339] & [1.462] & [1.308] & {$[1.556]$} & [2.186] \\
\hline \multirow[t]{2}{*}{ Current Account to GDP } & $0.046 * *$ & $0.046 * *$ & $0.031 * * *$ & $0.043 * *$ & 0.047 & 0.05 & $0.058 * *$ & $0.043 * *$ \\
\hline & {$[2.518]$} & [2.498] & {$[2.625]$} & [2.315] & [1.516] & [1.613] & {$[2.462]$} & [2.304] \\
\hline \multirow[t]{2}{*}{ Lag of broad money growth } & & & & -0.013 & & & & \\
\hline & & & & {$[-0.607]$} & & & & \\
\hline \multirow[t]{2}{*}{ Fixed exchange rate dummy (FEXD) } & & & & & & & & 0.006 \\
\hline & & & & & & & & [1.198] \\
\hline \multirow[t]{2}{*}{ Foreign ownership dummy (FOD) } & & & & & & & & $-0.007 * *$ \\
\hline & & & & & & & & {$[-1.982]$} \\
\hline \multirow[t]{2}{*}{ Interaction UMPM and (FEXD) } & & & & & & & & 0.019 \\
\hline & & & & & & & & {$[0.158]$} \\
\hline \multirow[t]{2}{*}{ Interaction UMPM and (FOD) } & & & & & & & & 0.243 \\
\hline & & & & & & & & [1.644] \\
\hline \multirow[t]{2}{*}{ Constant } & $0.022 * * *$ & $0.023 * * *$ & $0.020 * * *$ & $0.022 * * *$ & -0.01 & -0.012 & $0.023^{* * *}$ & $0.026 * * *$ \\
\hline & [7.833] & [8.355] & [10.281] & [7.611] & {$[-0.483]$} & {$[-0.537]$} & [7.307] & [5.764] \\
\hline Number of observations & 4673 & 4517 & 4517 & 4436 & 939 & 1095 & 2900 & 4517 \\
\hline R2 & 0.101 & 0.102 & & 0.104 & 0.187 & 0.175 & 0.112 & 0.104 \\
\hline
\end{tabular}

Notes: The table reports the estimates of panel regressions with country and time fixed effects and clustered standard errors at the country level. The dependent variable is the growth of broad money (from SRF forms). Column 1 represents results for the whole sample of 131 countries. Columns 2 and 3 show the results for the whole sample, excluding the S4 countries, using fixed (column 2) and random (column 3 ) effects models. In column 4, the lag of the independent variable is added to the model. Columns 5 and 6 show the results for advanced economies, first excluding S4 countries from the sample (column 5) and then including them (column 6). Column 7 represents the results for EME countries. And column 8 represents the result for the whole sample, excluding the S4, controlling for two institutional variables exchange rate regime (Ilzetzki, Reinhart and Rogoff (2008)) and foreign ownership in banking sector (World Bank surveys on bank regulation). ${ }^{* \star *}$ indicate significance at 1 percent, ${ }^{* *}$ at 5 percent, and * at 10 percent, respectively. 
Table 3.3. Impact of UMPM Programs on Broad Money Growth

(Individual UMPM)

\begin{tabular}{|c|c|c|c|c|c|c|c|c|}
\hline & \multicolumn{8}{|c|}{ Broad money growth, SRF reporters (USD) } \\
\hline & \multirow[b]{2}{*}{ All } & \multicolumn{7}{|c|}{$A E$, excl. } \\
\hline & & Excl. S4 & Excl. S4 & Excl. S4 & S4 & $\mathrm{AE}$ & EME & Excl. S4 \\
\hline \multirow[t]{2}{*}{ Global banks interoffice claims } & $0.562 * * *$ & $0.555^{* * *}$ & $0.559 * * *$ & $0.584 * * *$ & $1.024 * * *$ & $0.977 * * *$ & $0.498 * * *$ & $0.560 * * *$ \\
\hline & [7.048] & {$[6.779]$} & {$[6.846]$} & [6.697] & [5.649] & [6.041] & {$[5.118]$} & {$[6.855]$} \\
\hline \multirow[t]{2}{*}{ USA LT IR, instrumented by the UMPM } & 0.08 & 0.074 & 0.033 & 0.091 & $0.533 * * *$ & $0.503 * * *$ & 0.024 & -0.197 \\
\hline & {$[0.819]$} & {$[0.740]$} & {$[0.341]$} & {$[0.898]$} & {$[3.846]$} & [4.095] & {$[0.181]$} & {$[-1.473]$} \\
\hline \multirow[t]{2}{*}{ UK LT IR, instrumented by the UMPM } & $-0.713 * * *$ & $-0.717 * * *$ & $-0.704 * * *$ & $-0.721 * * *$ & $-0.634 * *$ & $-0.657 * * *$ & $-0.659 * * *$ & $*-0.507 * * *$ \\
\hline & {$[-5.895]$} & {$[-5.786]$} & {$[-5.750]$} & {$[-5.657]$} & {$[-2.742]$} & {$[-3.159]$} & {$[-4.028]$} & {$[-4.002]$} \\
\hline \multicolumn{9}{|l|}{ Japan LT IR, instrumented by the } \\
\hline \multirow[t]{2}{*}{ UMPM } & $0.719 * * *$ & $0.740 * * *$ & $0.702^{* * *}$ & $0.717 * * *$ & 0.379 & $0.359^{*}$ & $0.806 * * *$ & $0.539 * * *$ \\
\hline & {$[5.824]$} & {$[5.824]$} & {$[5.707]$} & [5.459] & [1.686] & {$[1.865]$} & {$[4.750]$} & {$[3.835]$} \\
\hline \multirow[t]{2}{*}{ EA LT IR, instrumented by the UMPM } & $0.230 * *$ & $0.230^{*}$ & $0.300 * * *$ & $0.247^{* *}$ & -0.272 & -0.176 & $0.285^{* *}$ & $0.230^{*}$ \\
\hline & {$[2.025]$} & {$[1.980]$} & {$[2.613]$} & {$[2.085]$} & {$[-0.962]$} & {$[-0.667]$} & {$[2.069]$} & {$[1.958]$} \\
\hline \multirow[t]{2}{*}{ Change in VIX } & $-0.083 * * *$ & $-0.086 * * *$ & $-0.087 * * *$ & $-0.086 * * *$ & $-0.117 * * *$ & $-0.101 * * *$ & $-0.088 * * *$ & * $-0.086 * * *$ \\
\hline & {$[-7.276]$} & {$[-7.602]$} & {$[-7.710]$} & {$[-7.569]$} & {$[-4.234]$} & {$[-3.591]$} & {$[-6.166]$} & {$[-7.625]$} \\
\hline \multirow[t]{2}{*}{ Change in REER } & $-0.058 * * *$ & $-0.055^{* *}$ & $-0.049 * *$ & $-0.050 * *$ & -0.03 & -0.057 & $-0.077 * *$ & $-0.057 * *$ \\
\hline & {$[-2.628]$} & {$[-2.513]$} & {$[-2.367]$} & {$[-2.314]$} & {$[-0.672]$} & {$[-1.295]$} & {$[-2.252]$} & {$[-2.544]$} \\
\hline \multirow[t]{2}{*}{ GDP growth } & $0.068^{* * *}$ & $0.068 * * *$ & $0.082^{* *}$ & $0.090 * *$ & $0.093^{* *}$ & $0.097^{* *}$ & $0.067^{* *}$ & $0.067^{* *}$ \\
\hline & {$[2.641]$} & {$[2.635]$} & {$[2.525]$} & [2.068] & {$[2.664]$} & {$[2.790]$} & {$[2.322]$} & [2.603] \\
\hline \multirow[t]{2}{*}{ Inflation } & $0.061 * *$ & $0.061^{* *}$ & $0.093^{* * *}$ & $0.060 * *$ & $0.168^{* *}$ & $0.165^{* *}$ & $0.087^{* *}$ & $0.061 * *$ \\
\hline & {$[2.029]$} & {$[2.025]$} & [3.828] & {$[2.030]$} & {$[2.643]$} & [2.798] & {$[2.208]$} & {$[2.077]$} \\
\hline \multirow[t]{2}{*}{ Policy rate differentional } & -0.078 & -0.082 & -0.082 & -0.087 & $0.531 * *$ & $0.634^{* *}$ & $-0.153^{* *}$ & -0.086 \\
\hline & {$[-0.905]$} & {$[-0.964]$} & {$[-1.051]$} & {$[-1.015]$} & {$[2.223]$} & {$[2.675]$} & {$[-2.112]$} & {$[-0.994]$} \\
\hline \multirow[t]{2}{*}{ Capital Account Openess } & -0.001 & -0.001 & -0.001 & 0 & 0.012 & 0.012 & -0.002 & -0.001 \\
\hline & {$[-0.181]$} & {$[-0.181]$} & {$[-0.892]$} & {$[0.106]$} & [1.039] & [1.029] & {$[-0.617]$} & {$[-0.211]$} \\
\hline \multirow[t]{2}{*}{ Export growth } & $0.016 * *$ & $0.016 * *$ & $0.020 * *$ & $0.017^{* *}$ & $0.016^{*}$ & 0.014 & 0.016 & $0.015^{*}$ \\
\hline & {$[2.041]$} & {$[2.061]$} & {$[2.510]$} & [2.193] & {$[1.765]$} & [1.653] & [1.423] & {$[1.977]$} \\
\hline \multirow[t]{2}{*}{ Current Account to GDP } & $0.041 * *$ & $0.041 * *$ & $0.030 * *$ & $0.038^{* *}$ & $0.062^{*}$ & $0.064^{*}$ & $0.051 * *$ & $0.037^{* *}$ \\
\hline & {$[2.187]$} & [2.159] & {$[2.506]$} & [2.029] & [1.888] & [1.965] & {$[2.142]$} & [1.999] \\
\hline \multirow[t]{2}{*}{ Lag of broad money growth } & & & & -0.015 & & & & \\
\hline & & & & {$[-0.713]$} & & & & \\
\hline \multirow[t]{2}{*}{ Fixed exchange rate dummy (FEXD) } & & & & & & & & 0.007 \\
\hline & & & & & & & & {$[1.400]$} \\
\hline \multirow[t]{2}{*}{ Foreign ownership dummy (FOD) } & & & & & & & & $-0.008 * *$ \\
\hline & & & & & & & & {$[-2.061]$} \\
\hline \multirow[t]{2}{*}{ Interaction UMPM and (FEXD) } & & & & & & & & 0.046 \\
\hline & & & & & & & & {$[0.382]$} \\
\hline \multirow[t]{2}{*}{ Interaction UMPM and (FOD) } & & & & & & & & $0.330 * *$ \\
\hline & & & & & & & & [2.519] \\
\hline \multirow[t]{2}{*}{ Constant } & $0.024 * * *$ & $0.024 * * *$ & $0.022 * * *$ & $0.024 * * *$ & -0.01 & -0.012 & $0.024 * * *$ & $0.027 * * *$ \\
\hline & {$[8.384]$} & {$[8.936]$} & {$[10.650]$} & {$[7.955]$} & {$[-0.548]$} & {$[-0.612]$} & [7.478] & [5.989] \\
\hline Number of observations & 4673 & 4517 & 4517 & 4436 & 939 & 1095 & 2900 & 4517 \\
\hline $\mathbf{R 2}$ & 0.105 & 0.106 & & 0.107 & 0.193 & 0.18 & 0.117 & 0.109 \\
\hline
\end{tabular}

Notes: The table reports the estimates of panel regressions with country and time fixed effects and clustered standard errors at the country level. The dependent variable is the growth of broad money (from SRF forms). Column 1 represents results for the whole sample of 131 countries. Columns 2 and 3 show the results for the whole sample, excluding the S4 countries, using fixed (column 2) and random (column 3 ) effects models. In column 4 , the lag of the independent variable is added to the model. Columns 5 and 6 show the results for advanced economies, first excluding 54 countries from the sample (column 5) and then including them (column 6). Column 7 represents the results for EME countries. And column 8 represents the result for the whole sample, excluding the S4, controlling for two institutional variables exchange rate regime (Ilzetzki, Reinhart and Rogoff (2008)) and foreign ownership in banking sector (World Bank surveys on bank regulation). ${ }^{* * *}$ indicate significance at 1 percent, ${ }^{* *}$ at 5 percent, and ${ }^{*}$ at 10 percent, respectively. 
Table 3.4. Impact of UMPM programs on NFC Deposits Growth

(Total UMPM)

\begin{tabular}{|c|c|c|c|c|c|c|c|c|}
\hline & \multicolumn{8}{|c|}{ NFC deposits growth, SRF reporters (USD) } \\
\hline & \multirow[b]{2}{*}{ All } & \multicolumn{7}{|c|}{ AE, excl. } \\
\hline & & Excl. S4 & Excl. S4 & Excl. S4 & S4 & $\mathrm{AE}$ & EME & Excl. S4 \\
\hline \multirow[t]{2}{*}{ Global banks interoffice claims } & $0.624 * * *$ & $0.648 * * *$ & $0.665 * * *$ & $0.765^{* * *}$ & $0.655^{*}$ & 0.45 & $0.640 * * *$ & $0.648 * * *$ \\
\hline & {$[6.690]$} & {$[6.885]$} & [6.967] & [7.515] & [1.935] & {$[1.536]$} & {$[5.794]$} & [6.937] \\
\hline \multicolumn{9}{|l|}{ USA LT IR, instrumented by the } \\
\hline \multirow[t]{2}{*}{ UMPM } & $0.434 * * *$ & $0.428 * * *$ & $0.446 * * *$ & $0.491 * * *$ & $0.472 *$ & $0.514^{* *}$ & $0.449 * * *$ & 0.212 \\
\hline & [4.109] & [3.959] & [4.348] & [4.276] & {$[2.143]$} & [2.394] & [3.610] & {$[0.990]$} \\
\hline \multirow[t]{2}{*}{ Change in VIX } & $-0.111 * * *$ & $-0.113^{* * *}$ & $-0.114 * * *$ & $-0.109 * * *$ & -0.085 & -0.066 & $-0.127 * * *$ & $-0.113 * * *$ \\
\hline & {$[-5.384]$} & {$[-5.429]$} & {$[-5.626]$} & {$[-5.264]$} & {$[-1.194]$} & {$[-1.106]$} & {$[-5.152]$} & {$[-5.440]$} \\
\hline \multirow[t]{2}{*}{ Change in REER } & $-0.100 * *$ & $-0.106 * *$ & $-0.091 * *$ & $-0.070 *$ & 0.067 & 0.118 & $-0.179 * * *$ & $-0.107 * *$ \\
\hline & {$[-2.502]$} & {$[-2.605]$} & {$[-2.340]$} & {$[-1.796]$} & {$[0.406]$} & {$[0.741]$} & {$[-3.827]$} & {$[-2.612]$} \\
\hline \multirow[t]{2}{*}{ GDP glowth } & $0.319 * * *$ & $0.331 * * *$ & $0.384 * * *$ & $0.405^{* * *}$ & 0.394 & 0.357 & $0.391 * * *$ & $0.331 * * *$ \\
\hline & {$[3.611]$} & [3.750] & [4.493] & [4.744] & [1.619] & {$[1.515]$} & [3.159] & [3.740] \\
\hline \multirow[t]{2}{*}{ Inflation } & $0.092 * *$ & $0.094 * *$ & $0.086 * * *$ & $0.092^{*}$ & 0.04 & -0.026 & $0.105^{*}$ & $0.095 * *$ \\
\hline & {$[2.070]$} & [2.133] & [2.794] & [1.965] & [0.185] & {$[-0.128]$} & [1.778] & {$[2.161]$} \\
\hline \multirow[t]{2}{*}{ Policy rate differentional } & 0.047 & 0.041 & 0.037 & 0.023 & -0.029 & 0.089 & -0.062 & 0.047 \\
\hline & {$[0.458]$} & {$[0.398]$} & {$[0.384]$} & [0.203] & {$[-0.058]$} & [0.184] & {$[-0.443]$} & {$[0.456]$} \\
\hline \multirow[t]{2}{*}{ Capital Account Openess } & 0 & 0 & -0.001 & 0.003 & -0.024 & -0.025 & 0.002 & 0 \\
\hline & {$[0.080]$} & [0.102] & {$[-0.784]$} & [0.591] & {$[-1.107]$} & {$[-1.145]$} & {$[0.310]$} & {$[0.086]$} \\
\hline \multirow[t]{2}{*}{ Export growth } & $0.042 * * *$ & $0.042 * * *$ & $0.043 * * *$ & $0.050 * * *$ & 0.014 & 0.013 & $0.049 * * *$ & $0.042 * * *$ \\
\hline & {$[3.729]$} & [3.734] & {$[3.876]$} & [4.421] & [0.320] & {$[0.314]$} & [3.381] & [3.715] \\
\hline \multirow[t]{2}{*}{ Current Account to GDP } & $0.092 * * *$ & $0.091 * * *$ & $0.051 * * *$ & $0.090 * * *$ & 0.071 & 0.069 & $0.085^{* * *}$ & $0.092 * * *$ \\
\hline & {$[3.528]$} & [3.507] & [4.101] & [3.298] & [1.845] & [1.687] & {$[2.783]$} & [3.455] \\
\hline \multirow[t]{2}{*}{ Lag of NFCs deposit growth } & & & & $-0.127 * * *$ & & & & \\
\hline & & & & {$[-5.587]$} & & & & \\
\hline \multirow[t]{2}{*}{ Fixed exchange rate dummy (FEXD) } & & & & & & & & -0.001 \\
\hline & & & & & & & & {$[-0.148]$} \\
\hline \multirow[t]{2}{*}{ Foreign ownership dummy (FOD) } & & & & & & & & \\
\hline & & & & & & & & {$[-0.036]$} \\
\hline \multirow[t]{2}{*}{ Interaction UMPM and (FEXD) } & & & & & & & & 0.022 \\
\hline & & & & & & & & {$[0.087]$} \\
\hline \multirow[t]{2}{*}{ Interaction UMPM and (FOD) } & & & & & & & & 0.291 \\
\hline & & & & & & & & {$[1.115]$} \\
\hline \multirow[t]{2}{*}{ Constant } & $0.022 * * *$ & $0.022 * * *$ & $0.020 * * *$ & $0.023 * * *$ & 0.038 & 0.05 & $0.021 * * *$ & $0.022 * * *$ \\
\hline & {$[5.803]$} & {$[5.915]$} & [7.888] & [5.507] & [1.569] & [1.601] & [4.458] & [3.441] \\
\hline Number of observations & 3543 & 3441 & 3441 & 3379 & 323 & 425 & 2615 & 3441 \\
\hline $\mathbf{R} \mathbf{2}$ & 0.054 & 0.056 & & 0.074 & 0.06 & 0.049 & 0.065 & 0.056 \\
\hline
\end{tabular}

Notes: The table reports the estimates of panel regressions with country and time fixed effects and clustered standard errors at the country level. The dependent variable is the growth of NFC deposits (from SRF forms). Column 1 represents results for the whole sample of 131 countries. Columns 2 and 3 show the results for the whole sample, excluding the S4 countries, using fixed (column 2) and random (column 3) effects models. In column 4, the lag of the independent variable is added to the model. Columns 5 and 6 show the results for advanced economies, first excluding S4 countries from the sample (column 5) and then including them (column 6). Column 7 represents the results for EME countries. And column 8 represents the result for the whole sample, excluding the S4, controlling for two institutional variables exchange rate regime (llzetzki, Reinhart and Rogoff (2008)) and foreign ownership in banking sector (World Bank surveys on bank regulation). ${ }^{* *}$ indicate significance at 1 percent, ${ }^{* *}$ at 5 percent, and * at 10 percent, respectively. 
Table 3.5. Impact of UMPM Programs on NFC Deposits Growth

(Individual UMPM)

\begin{tabular}{|c|c|c|c|c|c|c|c|c|}
\hline & \multicolumn{8}{|c|}{ NFC deposits growth, SRF reporters (USD) } \\
\hline & \multirow[b]{2}{*}{ All } & \multicolumn{7}{|c|}{$A E$, excl. } \\
\hline & & Excl. S4 & Excl. S4 & Excl. S4 & S4 & $\mathrm{AE}$ & EME & Excl. S4 \\
\hline \multirow[t]{2}{*}{ Global banks interoffice claims } & $0.480 * * *$ & $0.493 * * *$ & $0.503 * * *$ & $0.612 * * *$ & 0.685 & 0.53 & $0.432 * * *$ & $0.494 * * *$ \\
\hline & {$[4.308]$} & {$[4.312]$} & {$[4.377]$} & {$[5.137]$} & {$[1.783]$} & {$[1.728]$} & {$[3.221]$} & {$[4.314]$} \\
\hline \multicolumn{9}{|l|}{ USA LT IR, instrumented by the } \\
\hline \multirow[t]{2}{*}{ UMPM } & 0.084 & 0.024 & 0.051 & 0.084 & $0.897 * *$ & $1.234 * *$ & -0.073 & -0.267 \\
\hline & {$[0.432]$} & [0.127] & [0.263] & [0.401] & {$[2.719]$} & {$[2.614]$} & {$[-0.306]$} & {$[-1.012]$} \\
\hline \multicolumn{9}{|l|}{ UK LT IR, instrumented by the } \\
\hline \multirow[t]{2}{*}{ UMPM } & $-1.313 * * *$ & $*-1.327 * * *$ & $*-1.374 * * *$ & $-1.429 * * *$ & -0.897 & -0.922 & $-1.367 * * *$ & ${ }^{*}-1.095^{* * *}$ \\
\hline & {$[-5.917]$} & {$[-5.812]$} & {$[-6.467]$} & {$[-5.843]$} & {$[-1.186]$} & {$[-1.750]$} & {$[-5.012]$} & {$[-4.819]$} \\
\hline \multicolumn{9}{|l|}{ Japan LT IR, instrumented by the } \\
\hline \multirow[t]{2}{*}{ UMPM } & $1.132 * * *$ & $1.148^{* * *}$ & $1.181^{* * *}$ & $1.147^{* * *}$ & 0.655 & 0.651 & $1.346 * * *$ & $0.913 * * *$ \\
\hline & [4.827] & {$[4.770]$} & {$[5.352]$} & {$[4.769]$} & {$[1.174]$} & {$[1.476]$} & [4.610] & {$[3.872]$} \\
\hline \multicolumn{9}{|l|}{ EA LT IR, instrumented by the } \\
\hline \multirow[t]{2}{*}{ UMPM } & $0.600 * * *$ & $0.674 * * *$ & $0.675^{* * *}$ & $0.767 * * *$ & -0.295 & -0.703 & $0.707^{* * *}$ & $0.692 * * *$ \\
\hline & {$[2.714]$} & {$[3.094]$} & {$[3.022]$} & {$[3.533]$} & {$[-0.404]$} & {$[-1.007]$} & {$[2.716]$} & {$[3.144]$} \\
\hline \multirow[t]{2}{*}{ Change in VIX } & $-0.102 * * *$ & * $-0.104^{* * *}$ & * $-0.105^{* * *}$ & $-0.098 * * *$ & -0.091 & -0.078 & $-0.117^{* * *}$ & ${ }^{*}-0.103^{* * *}$ \\
\hline & {$[-4.980]$} & {$[-4.979]$} & {$[-5.100]$} & {$[-4.855]$} & {$[-1.208]$} & {$[-1.238]$} & {$[-4.841]$} & {$[-4.978]$} \\
\hline \multirow[t]{2}{*}{ Change in REER } & $-0.100 * *$ & $-0.107^{* *}$ & $-0.091^{* *}$ & $-0.070^{*}$ & 0.073 & 0.124 & $-0.183 * * *$ & $-0.108 * *$ \\
\hline & {$[-2.477]$} & {$[-2.593]$} & {$[-2.312]$} & {$[-1.784]$} & {$[0.434]$} & {$[0.786]$} & {$[-3.853]$} & {$[-2.591]$} \\
\hline \multirow[t]{2}{*}{ GDP growth } & $0.334^{* * *}$ & $0.349 * * *$ & $0.401 * * *$ & $0.431^{* * *}$ & 0.375 & 0.325 & $0.400 * * *$ & $0.349 * * *$ \\
\hline & {$[3.813]$} & {$[4.002]$} & {$[4.751]$} & {$[5.135]$} & [1.437] & [1.309] & {$[3.260]$} & [3.989] \\
\hline \multirow[t]{2}{*}{ Inflation } & $0.102 * *$ & $0.107 * *$ & $0.094 * * *$ & $0.106^{* *}$ & -0.009 & -0.108 & $0.119 * *$ & $0.106^{* *}$ \\
\hline & {$[2.332]$} & [2.455] & [3.097] & {$[2.318]$} & {$[-0.042]$} & {$[-0.520]$} & {$[2.044]$} & {$[2.463]$} \\
\hline \multirow[t]{2}{*}{ Policy rate differentional } & 0.092 & 0.092 & 0.09 & 0.086 & -0.093 & -0.074 & 0.012 & 0.098 \\
\hline & {$[0.941]$} & {$[0.943]$} & {$[0.968]$} & {$[0.789]$} & {$[-0.165]$} & {$[-0.143]$} & {$[0.089]$} & [0.997] \\
\hline \multirow[t]{2}{*}{ Capital Account Openess } & 0 & 0 & -0.001 & 0.003 & -0.024 & -0.024 & 0.001 & 0 \\
\hline & {$[0.026]$} & {$[0.050]$} & {$[-0.767]$} & {$[0.515]$} & {$[-1.166]$} & {$[-1.219]$} & {$[0.254]$} & {$[0.006]$} \\
\hline \multirow[t]{2}{*}{ Export growth } & $0.040 * * *$ & $0.040 * * *$ & $0.041^{* * *}$ & $0.048^{* * *}$ & 0.017 & 0.019 & $0.046^{* * *}$ & $0.040^{* * *}$ \\
\hline & {$[3.592]$} & [3.577] & [3.709] & {$[4.262]$} & {$[0.368]$} & {$[0.430]$} & [3.241] & [3.509] \\
\hline \multirow[t]{2}{*}{ Current Account to GDP } & $0.083^{* * *}$ & $0.082 * * *$ & $0.048^{* * *}$ & $0.082 * * *$ & $0.091 * *$ & $0.099 * *$ & $0.072 * *$ & $0.084^{* * *}$ \\
\hline & {$[3.344]$} & [3.310] & {$[4.010]$} & [3.129] & {$[2.351]$} & {$[2.545]$} & {$[2.561]$} & {$[3.255]$} \\
\hline Lag of NFCs deposit growth & & & & $\begin{array}{l}-0.129 * * * \\
{[-5.740]}\end{array}$ & & & & \\
\hline Fixed exchange rate dummy (FEXD) & & & & & & & & -0.001 \\
\hline & & & & & & & & {$[-0.058]$} \\
\hline Foreign ownership dummy (FOD) & & & & & & & & 0 \\
\hline & & & & & & & & {$[-0.014]$} \\
\hline Interaction UMPM and (FEXD) & & & & & & & & 0.055 \\
\hline & & & & & & & & {$[0.218]$} \\
\hline Interaction UMPM and (FOD) & & & & & & & & 0.369 \\
\hline & & & & & & & & {$[1.425]$} \\
\hline Constant & $0.023^{* * *}$ & $0.023^{* * *}$ & $0.022^{* * *}$ & $0.024 * * *$ & $0.039 *$ & $0.051^{*}$ & $0.023 * * *$ & $0.023 * * *$ \\
\hline & {$[5.788]$} & {$[5.877]$} & {$[8.266]$} & [5.424] & [1.871] & [1.849] & {$[4.523]$} & {$[3.512]$} \\
\hline Number of observations & 3543 & 3441 & 3441 & 3379 & 323 & 425 & 2615 & 3441 \\
\hline R2 & 0.058 & 0.061 & & 0.079 & 0.062 & 0.054 & 0.072 & 0.062 \\
\hline
\end{tabular}

Notes: The table reports the estimates of panel regressions with country and time fixed effects and clustered standard errors at the country level. The dependent variable is the growth of NFC deposits (from SRF forms). Column 1 represents results for the whole sample of 131 countries. Columns 2 and 3 show the results for the whole sample, excluding the S4 countries, using fixed (column 2) and random (column 3) effects models. In column 4, the lag of the independent variable is added to the model. Columns 5 and 6 show the results for advanced economies, first excluding S4 countries from the sample (column 5) and then including them (column 6). Column 7 represents the results for EME countries. And column 8 represents the result for the whole sample, excluding the S4, controlling for two institutional variables exchange rate regime (Ilzetzki, Reinhart and Rogoff (2008)) and foreign ownership in banking sector (World Bank surveys on bank regulation). ${ }^{* *}$ indicate significance at 1 percent, ${ }^{* *}$ at 5 percent, and ${ }^{*}$ at 10 percent, respectively. 
Table 3.6. Impact of UMPM Programs on NFC Securities' Issuance

(Total UMPM)

\begin{tabular}{|c|c|c|c|c|c|c|c|c|}
\hline & \multicolumn{8}{|c|}{ NFC Securities' Issuance (in percent of GDP) } \\
\hline & \multirow[b]{2}{*}{ All } & \multicolumn{7}{|c|}{$\mathrm{AE}$, excl. } \\
\hline & & Excl. S4 & Excl. S4 & Excl. S4 & S4 & $\mathrm{AE}$ & EME & Excl. S4 \\
\hline \multirow[t]{2}{*}{ Global banks interoffice claims } & -0.023 & -0.019 & -0.021 & -0.023 & -0.035 & -0.043 & -0.003 & -0.017 \\
\hline & {$[-1.439]$} & {$[-1.154]$} & {$[-1.275]$} & {$[-1.415]$} & {$[-0.826]$} & {$[-1.258]$} & {$[-0.185]$} & {$[-1.057]$} \\
\hline \multicolumn{9}{|c|}{ USA LT IR, instrumented by UMPM } \\
\hline \multirow[t]{2}{*}{ in S4 } & -0.021 & -0.024 & -0.024 & -0.046 & -0.1 & -0.076 & -0.006 & 0.011 \\
\hline & {$[-0.822]$} & {$[-0.868]$} & {$[-0.874]$} & {$[-1.608]$} & {$[-1.490]$} & {$[-1.336]$} & {$[-0.235]$} & {$[0.170]$} \\
\hline \multirow[t]{2}{*}{ Change in VIX } & $-0.017 * * *$ & $-0.015 * * *$ & $-0.015 * * *$ & $-0.017 * * *$ & $-0.031 * * *$ & $-0.032 * * *$ & $-0.010 * * *$ & $-0.015 * * *$ \\
\hline & {$[-5.136]$} & {$[-4.683]$} & {$[-4.668]$} & {$[-4.730]$} & {$[-4.273]$} & {$[-5.111]$} & {$[-3.049]$} & {$[-4.696]$} \\
\hline \multirow[t]{2}{*}{ Change in REER } & -0.006 & -0.008 & -0.007 & -0.009 & -0.037 & -0.024 & 0.001 & -0.008 \\
\hline & {$[-0.829]$} & {$[-1.082]$} & {$[-1.020]$} & {$[-1.242]$} & {$[-1.296]$} & {$[-0.971]$} & {$[0.136]$} & {$[-1.032]$} \\
\hline \multirow[t]{2}{*}{ GDP growth } & -0.002 & 0 & -0.002 & 0.001 & 0.026 & 0.025 & -0.012 & 0 \\
\hline & {$[-0.136]$} & {$[-0.029]$} & {$[-0.140]$} & [0.048] & [1.170] & [1.148] & {$[-0.574]$} & {$[-0.040]$} \\
\hline \multirow[t]{2}{*}{ Inflation } & 0.001 & 0.001 & -0.007 & 0.003 & 0.112 & 0.099 & -0.012 & 0.001 \\
\hline & {$[0.071]$} & [0.099] & {$[-0.854]$} & [0.347] & [1.425] & [1.323] & {$[-1.508]$} & {$[0.105]$} \\
\hline \multirow[t]{2}{*}{ Policy rate differentional } & -0.001 & -0.004 & -0.008 & -0.008 & -0.092 & -0.069 & -0.005 & -0.005 \\
\hline & {$[-0.071]$} & {$[-0.330]$} & {$[-0.655]$} & {$[-0.695]$} & {$[-1.742]$} & {$[-1.327]$} & {$[-0.353]$} & {$[-0.393]$} \\
\hline \multirow[t]{2}{*}{ Capital Account Openess } & -0.001 & -0.001 & 0 & -0.001 & $0.005^{* * *}$ & $0.004 * * *$ & -0.002 & -0.001 \\
\hline & {$[-1.051]$} & {$[-1.047]$} & {$[-0.267]$} & {$[-1.052]$} & [3.463] & [3.175] & {$[-1.231]$} & {$[-1.132]$} \\
\hline \multirow[t]{2}{*}{ Export growth } & 0 & 0.001 & 0.001 & 0.001 & -0.004 & -0.005 & 0.003 & 0.001 \\
\hline & {$[0.130]$} & {$[0.354]$} & [0.310] & [0.239] & {$[-0.697]$} & {$[-0.836]$} & [1.339] & {$[0.380]$} \\
\hline \multirow[t]{2}{*}{ Current Account to GDP } & -0.001 & -0.002 & 0.004 & -0.002 & -0.011 & -0.01 & 0.001 & -0.004 \\
\hline & {$[-0.183]$} & {$[-0.241]$} & {$[0.745]$} & {$[-0.312]$} & {$[-0.413]$} & {$[-0.389]$} & [0.093] & {$[-0.546]$} \\
\hline \multirow[t]{2}{*}{ Total banks' assets } & 0.002 & 0.002 & 0.001 & 0.003 & 0.016 & 0.013 & 0.003 & 0.002 \\
\hline & {$[0.507]$} & [0.543] & [0.293] & [0.602] & [1.212] & [1.032] & [0.988] & {$[0.615]$} \\
\hline \multirow{3}{*}{$\begin{array}{l}\text { Lag of NFC Securities' Issuance (in } \\
\text { percent of GDP) }\end{array}$} & & & & & & & & \\
\hline & & & & 0.082 & & & & \\
\hline & & & & [1.584] & & & & \\
\hline \multirow[t]{2}{*}{ Fixed exchange rate dummy (FEXD) } & & & & & & & & $0.001 * *$ \\
\hline & & & & & & & & {$[2.215]$} \\
\hline \multirow[t]{2}{*}{ Foreign ownership dummy (FOD) } & & & & & & & & -0.002 \\
\hline & & & & & & & & {$[-1.150]$} \\
\hline \multirow[t]{2}{*}{ Interaction UMPM and (FEXD) } & & & & & & & & -0.065 \\
\hline & & & & & & & & {$[-1.063]$} \\
\hline \multirow[t]{2}{*}{ Interaction UMPM and (FOD) } & & & & & & & & -0.026 \\
\hline & & & & & & & & {$[-0.403]$} \\
\hline \multirow[t]{2}{*}{ Constant } & $0.012 * * *$ & $0.011 * * *$ & $0.010 * * *$ & $0.010 * * *$ & 0.004 & $0.008 * *$ & $0.009 * * *$ & $0.012^{* * *}$ \\
\hline & [8.403] & [7.852] & [4.406] & [6.382] & [1.316] & [2.291] & [7.745] & [6.973] \\
\hline Number of observations & 2236 & 2089 & 2089 & 2058 & 636 & 783 & 1333 & 2089 \\
\hline R2 & 0.017 & 0.015 & & 0.024 & 0.05 & 0.053 & 0.013 & 0.016 \\
\hline
\end{tabular}

Notes: The table reports the estimates of panel regressions with country and time fixed effects and clustered standard errors at the country level. The dependent variable is the growth of NFC securities issuance. Column 1 represents results for the whole sample of 131 countries. Columns 2 and 3 show the results for the whole sample, excluding the S4 countries, using fixed (column 2) and random (column 3 ) effects models. In column 4, the lag of the independent variable is added to the model. Columns 5 and 6 show the results for advanced economies, first excluding $\$ 4$ countries from the sample (column 5 ) and then including them (column 6). Column 7 represents the results for EME countries. And column 8 represents the result for the whole sample, excluding the S4, controlling for two institutional variables exchange rate regime (Ilzetzki, Reinhart and Rogoff (2008)) and foreign ownership in banking sector (World Bank surveys on bank regulation). ${ }^{* *}$ indicate significance at 1 percent, ${ }^{* *}$ at 5 percent, and ${ }^{*}$ at 10 percent, respectively. 
Table 3.7. Impact of UMPM Programs on NFC Securities' Issuance

(Individual UMPM)

\begin{tabular}{|c|c|c|c|c|c|c|c|c|}
\hline & \multicolumn{8}{|c|}{ NFC Securities' Issuance (in percent of GDP) } \\
\hline & \multirow[b]{2}{*}{ All } & \multicolumn{7}{|c|}{$\mathrm{AE}$, excl. } \\
\hline & & Excl. S4 & Excl. S4 & Excl. S4 & S4 & $\mathrm{AE}$ & EME & Excl. S4 \\
\hline \multirow[t]{2}{*}{ Global banks interoffice claims } & $0.034 * *$ & $0.033^{*}$ & $0.032^{*}$ & 0.029 & $0.056^{*}$ & $0.052^{*}$ & \multicolumn{2}{|c|}{$0.0330 .034^{*}$} \\
\hline & [2.064] & [1.906] & [1.859] & [1.641] & [1.779] & [2.006] & [1.380] & [1.944] \\
\hline \multirow[t]{2}{*}{ USA LT IR, instrumented by the UMPM } & 0.009 & -0.008 & -0.002 & -0.012 & -0.137 & -0.058 & 0.036 & 0.023 \\
\hline & [0.177] & {$[-0.149]$} & {$[-0.029]$} & {$[-0.226]$} & {$[-0.969]$} & {$[-0.470]$} & {$[0.766]$} & {$[0.283]$} \\
\hline \multirow[t]{2}{*}{ UK LT IR, instrumented by the UMPM } & $0.279 * * *$ & $0.280 * * *$ & $0.284 * * *$ & $0.268 * * *$ & $0.539 *$ & $0.478 * *$ & $0.186^{* *}$ & $0.257^{* *}$ \\
\hline & {$[3.034]$} & {$[2.865]$} & {$[2.854]$} & [2.985] & [2.098] & {$[2.259]$} & [2.111] & {$[2.479]$} \\
\hline \multicolumn{9}{|l|}{ Japan LT IR, instrumented by the } \\
\hline \multirow[t]{2}{*}{ UMPM } & $-0.358 * * *$ & $-0.354 * * *$ & $-0.352 * * *$ & $-0.333^{* * *}$ & $-0.690 * * *$ & $-0.637 * * *$ & $-0.231 * *$ & $-0.328 * * *$ \\
\hline & {$[-4.392]$} & {$[-4.081]$} & {$[-4.023]$} & {$[-4.194]$} & {$[-3.868]$} & {$[-4.163]$} & {$[-2.649]$} & {$[-3.902]$} \\
\hline \multirow[t]{2}{*}{ EA LT IR, instrumented by the UMPM } & $0.087^{*}$ & $0.105^{* *}$ & $0.090 * *$ & $0.086^{*}$ & $0.275^{* *}$ & $0.189^{*}$ & 0.047 & $0.099 * *$ \\
\hline & [1.978] & [2.297] & {$[2.006]$} & [1.852] & [2.910] & {$[2.084]$} & {$[0.893]$} & {$[2.205]$} \\
\hline \multirow[t]{2}{*}{ Change in VIX } & $-0.015 * * *$ & $-0.014^{* * *}$ & $-0.013 * * *$ & $-0.014 * * *$ & $-0.025 * * *$ & $-0.028 * * *$ & $-0.010 * * *$ & $-0.014 * * *$ \\
\hline & {$[-4.716]$} & {$[-4.282]$} & {$[-4.286]$} & {$[-4.221]$} & {$[-3.772]$} & {$[-4.598]$} & {$[-2.741]$} & {$[-4.293]$} \\
\hline \multirow[t]{2}{*}{ Change in REER } & -0.006 & -0.008 & -0.007 & -0.008 & -0.043 & -0.026 & 0.002 & -0.008 \\
\hline & {$[-0.804]$} & {$[-1.118]$} & {$[-1.023]$} & {$[-1.163]$} & {$[-1.576]$} & {$[-1.093]$} & {$[0.288]$} & {$[-1.065]$} \\
\hline \multirow[t]{2}{*}{ GDP growth } & 0.004 & 0.006 & 0.004 & 0.005 & 0.033 & 0.029 & -0.005 & 0.005 \\
\hline & {$[0.318]$} & {$[0.425]$} & {$[0.274]$} & [0.398] & {$[1.300]$} & {$[1.227]$} & {$[-0.194]$} & {$[0.413]$} \\
\hline \multirow[t]{2}{*}{ Inflation } & 0.008 & 0.01 & 0.001 & 0.01 & $0.116^{*}$ & 0.097 & -0.006 & 0.01 \\
\hline & {$[0.966]$} & [1.109] & {$[0.069]$} & [1.135] & [1.792] & {$[1.506]$} & {$[-0.951]$} & [1.094] \\
\hline \multirow[t]{2}{*}{ Policy rate differentional } & 0.002 & 0.001 & -0.004 & -0.004 & -0.063 & -0.056 & -0.001 & 0.001 \\
\hline & {$[0.194]$} & {$[0.072]$} & {$[-0.347]$} & {$[-0.343]$} & {$[-1.531]$} & {$[-1.402]$} & {$[-0.073]$} & {$[0.076]$} \\
\hline \multirow[t]{2}{*}{ Capital Account Openess } & -0.001 & -0.001 & 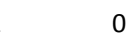 & -0.001 & 0.003 & $0.003^{*}$ & -0.001 & -0.001 \\
\hline & {$[-0.985]$} & {$[-0.972]$} & {$[0.006]$} & {$[-0.913]$} & {$[1.697]$} & [1.909] & {$[-1.261]$} & {$[-1.075]$} \\
\hline \multirow[t]{2}{*}{ Export growth } & 0.001 & 0.002 & 0.002 & 0.002 & -0.003 & -0.004 & 0.004 & 0.002 \\
\hline & {$[0.760]$} & {$[0.904]$} & {$[0.881]$} & {$[0.822]$} & {$[-0.622]$} & {$[-0.709]$} & [1.593] & {$[0.952]$} \\
\hline \multirow[t]{2}{*}{ Current Account to GDP } & 0 & 0 & 0.005 & -0.001 & -0.026 & -0.021 & 0.003 & -0.002 \\
\hline & {$[0.035]$} & {$[-0.074]$} & {$[0.907]$} & {$[-0.161]$} & {$[-1.043]$} & {$[-0.911]$} & [0.617] & {$[-0.361]$} \\
\hline \multirow[t]{2}{*}{ Total banks' assets } & 0.003 & 0.003 & 0.002 & 0.004 & 0.02 & 0.017 & 0.004 & 0.003 \\
\hline & {$[0.833]$} & {$[0.813]$} & {$[0.544]$} & {$[0.867]$} & {$[1.615]$} & {$[1.527]$} & {$[1.062]$} & {$[0.826]$} \\
\hline \multirow{3}{*}{$\begin{array}{l}\text { Lag of NFC Securities' Issuance (in } \\
\text { percent of GDP) }\end{array}$} & & & & & & & & \\
\hline & & & & 0.062 & & & & \\
\hline & & & & {$[1.256]$} & & & & \\
\hline Fixed exchange rate dummy (FEXD) & & & & & & & & \\
\hline & & & & & & & & {$[-0.073]$} \\
\hline Foreign ownership dummy (FOD) & & & & & & & & -0.002 \\
\hline & & & & & & & & {$[-0.996]$} \\
\hline Interaction UMPM and (FEXD) & & & & & & & & -0.056 \\
\hline & & & & & & & & {$[-0.922]$} \\
\hline Interaction UMPM and (FOD) & & & & & & & & -0.021 \\
\hline & & & & & & & & {$[-0.460]$} \\
\hline Constant & $0.010 * * *$ & $0.008^{* * *}$ & $0.007 * * *$ & $0.008 * * *$ & 0.004 & $0.007 *$ & $0.007 * * *$ & $0.009 * * *$ \\
\hline & [7.811] & {$[6.777]$} & [3.893] & [5.533] & [1.008] & {$[1.810]$} & [6.943] & {$[6.402]$} \\
\hline Number of observations & 2236 & 2089 & 2089 & 2058 & 636 & 783 & 1333 & 2089 \\
\hline R2 & 0.043 & 0.04 & & 0.044 & 0.111 & 0.109 & 0.027 & 0.041 \\
\hline
\end{tabular}

Notes: The table reports the estimates of panel regressions with country and time fixed effects and clustered standard errors at the country level. The dependent variable is the growth of NFC securities issuance. Column 1 represents results for the whole sample of 131 countries. Columns 2 and 3 show the results for the whole sample, excluding the $\$ 4$ countries, using fixed (column 2) and random (column 3 ) effects models. In column 4 , the lag of the independent variable is added to the model. Columns 5 and 6 show the results for advanced economies, first excluding 54 countries from the sample (column 5) and then including them (column 6). Column 7 represents the results for EME countries. And column 8 represents the result for the whole sample, excluding the S4, controlling for two institutional variables exchange rate regime (Ilzetzki, Reinhart and Rogoff (2008)) and foreign ownership in banking sector (World Bank surveys on bank regulation). ${ }^{* *}$ indicate significance at 1 percent, ${ }^{* *}$ at 5 percent, and * at 10 percent, respectively. 


\section{REFERENCES}

Ahmed, Shaghil and Andrei Zlate, 2013, "Capital Flows to Emerging Market Economies," Board of Governors of the Federal Reserve System, International Finance Discussion Paper No. 1081.

Arellano, Manuel and Olympia. Bover, 1995, "Another Look at the Instrumental Variable Estimation of Error-Component Models," Journal of Econometrics, Vol. 68, Iss. 1, pp. 29-51.

Bank for International Settlements, 2010, "Funding patterns and liquidity management of internationally active banks”, CGFS paper 39, May 2010, http://www.bis.org/publ/cgfs39.htm

Bank for International Settlements, 2012, "Residency/Local and Nationality/Global Views of Financial Positions” IFC Working Paper No 8, BIS Irving Fisher Committee, http://www.bis.org/ifc/publ/ifcwork08.htm

Bank for International Settlements. 2013, "Emerging market debt securities issuance in offshore centers” BIS Quarterly Review, September 2013, pp. 22-23 https://www.bis.org/publ/qtrpdf/r_qt1309w.htm

Basel Committee on Banking Supervision, 2009, "Strengthening the Resilience of the Banking Sector,” December 2009, http://www.bis.org/publ/bcbs164.pdf

Basel Committee on Banking Supervision, 2010, "International regulatory framework for banks (Basel III),” Bank for International Settlements, http://www.bis.org/bcbs/basel3.htm

Bean, Charlie, 2013, “Global Aspects of Unconventional Monetary policy,” Bank of England, Speech delivered at the Federal Reserve Bank of Kansas City Economic Policy Symposium, Jackson hole, Wyoming, 24 August 2013, http://www.bankofengland.co.uk/publications/Documents/speeches/2013/speech674. pdf.

Boeckx, Jef, Maarten Dossche, and Gert Peersman, 2014, "Effectiveness and Transmission of the ECB's Balance Sheet Policies," CESifo Working Paper Series 4907, CESifo Group Munich.

Borio, Claudio and Philip Lowe, 2002, “Asset Prices, Financial and Monetary Stability: Exploring the Nexus,” BIS Working Paper, No. 114, Basel: Bank for International Settlements, July. 
Borio, Claudio and Philip Lowe, 2004, "Securing sustainable price stability: should credit come back from the wilderness?” BIS Working Paper, No.157.

Bruno, Valentina and Hyun Song Shin, 2012, "Capital Flows and the Risk-Taking Channel of Monetary Policy,” NBER Working Paper 18942, http://www.princeton.edu/ hsshin/www/capital_flows_risk-taking_channel.pdf

Bruno, Valentina and Hyun Song Shin, 2013, "Cross-Border Banking and Global Liquidity," http://www.princeton.edu/ hsshin/www/capital_flows_global_liquidity.pdf

Burns, Andrew, Mizuho Kida, Jamus Jerome Lim, Sanket Mohapatra, and Marc Stocker, 2014, "Unconventional Monetary Policy Normalization in High-Income Countries: Implications for Emerging Market Capital Flows and Crisis risks," the World Bank, Policy Research Working Paper No. 6830.

Butt, Nicholas, Silvia Domit, Lewis Kirkham, Michael McLeay, and Ryland Thomas, , 2012, 'What can the money data tell us about the impact of QE?', Bank of England Quarterly Bulletin, Vol. 52, No. 4, pages 321-31.

Butt, Nicholas, Rohan Churm , Michael McMahon, Arpad Morotz, and Jochen Schanz, , 2014, “QE and the bank lending channel in the United Kingdom”, Bank of England, Working paper, No. 511.

Canning, David and Peter Pedroni, 2008, "Infrastructure, Long-Run Economic Growth and Causality Tests for Cointegrated Panels," The Manchester School, 76 (5), pp.504-27.

Casiraghi, Marco, Eugenio Gaiotti, Lisa Rodano, and Alessandro Secchi, 2013, "The impact of unconventional monetary policy on the Italian economy during the sovereign debt crisis”, Bank of Italy, Occasional Papers, No. 203.

Chen, Qianying, Andrew Filardo, Dong He and Feng Zhu, 2013, "International spillovers of central bank balance sheet policies", BIS Papers No 66.

Chen, Qianying, Andrew Filardo, Dong He, and Feng Zhu, 2015, "Financial crisis, US unconventional monetary policy and international spillovers", BIS Papers No 494.

Chung, Kyuil, Hail Park, and Hyun Song Shin, 2012, "Mitigating Spillover Effects from Currency Hedging,” National Institute Economic Review, NIESR, London.

Chung, Kyuil, Jong-Eun Lee, Elena Loukoianova, Hail Park, and Hyun Song Shin, 2014, "Global Liquidity through the Lens of Monetary Aggregates," IMF Working Paper, $\mathrm{WP} / 14 / 09$. 
Constancio, Vitor, 2014, "A New Phase of the ECB's Monetary Policy," Speech at the "ECB's workshop on non-standard monetary policy measures," Frankfurt Am Main, 6 October 2014, https://www.ecb.europa.eu/press/key/date/2014/html/sp141006.en.html

Cour-Thimann, Philippine and Bernhard Winkler, 2013, “The ECB's Non-Standard Monetary Policy Measures: The Role of Institutional Factors and Financial Structure," ECB Working Paper Series, No 1528/April 2013, https://www.ecb.europa.eu/pub/pdf/scpwps/ecbwp1528.pdf?020110fe7ca57b9db2a4d $\underline{7 d c 4 b a 3 e c 3 a}$

D’Amico, Stefania, William English, David Lopez-Salido, and Edward Nelson, 2012, "The Federal Reserve's Large-Scale Asset Purchase Programmes: Rationale and Effects," Economic Journal, vol. 122 (November), pp. F415-46.

D'Amico Stefania and Thomas B. King, 2013, "Flow and stock effects of large-scale treasury purchases: Evidence on the importance of local supply," Journal of Financial Economics, vol. 108, issue, 2, pp. 425-448.

Edge, Rochelle M. and Ralf R. Meisenzahl, 2011, “The Unreliability of Credit-to-GDP Ratio Gaps in Real Time: Implications for Countercyclical Capital Buffers," International Journal of Central Banking, vol. 7, pp. 261-298.

Engen, Eric, Thomas Laubach, and David Reifschneider, 2015, "The Macroeconomic Effects of the Federal Reserve's Unconventional Monetary Policies," Finance and Economics Discussion Series 2015-005 (Washington: Board of Governors of the Federal Reserve System, January), http://dx.doi.org/10.17016/FEDS.2015.005.

European Central Bank, 2015, "The role of the central bank balance sheet in monetary policy”, ECB Economic Bulletin, Issue 4, 2015.

Evans, Charles, 2013, "How Much Longer? (Only the Data Know)," Chicago Fed, Speech delivered on October 17, 2013, at the 2013 Wisconsin Real Estate and Economic Outlook Conference, Madison, Wisconsin, http://www.chicagofed.org/webpages/publications/speeches/2013/10 $17 \quad 13$ how m uch longer university wisconsin.cfm

Fischer Stanley, 2015, “Conducting Monetary Policy with a Large balance Sheet”, Speech delivered on February 27, 2015, at the 2015 U.S. Monetary Policy Forum, Sponsored by the University of Chicago Booth School of Business, New York, New York, http://www.federalreserve.gov/newsevents/speech/fischer20150227a.pdf 
Filardo, Andrew and James Yetman, 2012, "The expansion of central bank balance sheets in emerging Asia: what are the risks?” BIS Quarterly Review, June 2012, pp. 47-63, http://www.bis.org/publ/qtrpdf/r_qt1206g.pdf

Ficher, Paul, 2013, "Financial Markets, Monetary policy, and Credit Supply,” Bank of England, Speech given at Richmond University, London, October 2, 2013, http://www.bankofengland.co.uk/publications/Documents/speeches/2013/speech683. pdf.

Forbex Kristin J. and Francis E. Warnock, 2012, "Capital Flow Waves: Surges, Stops, Flight, and Retrenchment," Journal of International Economics, Vol. 88, Iss. 2, pp. 235-51.

Fratzscher Marcel, Marco Lo Duca, and Roland Straub, 2012, “A Global monetary Tsunami? On the Spillovers of U.S. Quantitative easing," CEPR Discussion Paper 9195.

Friedman, Benjamin M., 1988, "Lessons on Monetary Policy from the 1980s," Journal of Economic Perspectives, 2, pp. 51-72.

Friedman, Benjamin M., 2013, “The Simple Analytics of Monetary Policy: A Post-Crisis Approach," paper presented at the January 2013 American Economic Association meeting.

Friedman, Milton, 1956, "The Quantity Theory of Money - A Restatement," in Studies in the Quantity Theory of Money (ed) Milton Friedman, Chicago University Press, Chicago.

Gagnon, Joseph, Matthew Raskin, Julie Remache, and Brian Sack, 2011, "The Financial Market Effects of the Federal Reserve's Large-Scale Asset Purchases," International Journal of Central Banking, vol. 7 (March), pp. 3-43, www.ijcb.org/journal/ijcb11q1a1.pdf.

Ghosh, Atish R., Mahvash Saeed Qureshi, Juan Zalduendo, and Jun Il Kim, 2013, "Surges," IMF Working Paper, WP/12/22.

Hahm, Joon-Ho, Hyun Song Shin, and Kwanho Shin, 2013, "Non-Core Bank Liabilities and Financial Vulnerability," Journal of Money, Credit and Banking, 45(S1), pp. 3-36.

Hamilton, James and Jing (Cynthia) Wu, 2012, “The Effectiveness of Alternative Monetary Policy Tools in a Zero Lower Bound Environment," Journal of Money, Credit and Banking, vol. 44, pp. 3-46.

Hattori, Masazumi, Hyun Song Shin, and Wataru Takahashi, 2009, “A Financial System Perspective on Japan's Experience in the Late 1980s," paper presented at the 16th 
Bank of Japan International Conference, May 2009, Bank of Japan IMES discussion paper, http://www.imes.boj.or.jp/english/publication/edps/2009/09-E-19.pdf

Ihrig, Jane, Elizabeth Klee, Canlin Li, Brett Schulte, and Min Wei, 2012, "Expectations about the Federal Reserve's Balance Sheet and the Term Structure of Interest Rates," Finance and Economics Discussion Series 2012-57 (Washington: Board of Governors of the Federal Reserve System, July), www.federalreserve.gov/pubs/feds/2012/201257/201257pap.pdf

International Monetary Fund, 2013a, IMF Multilateral Policy Issues Report, 2013 Spillover Report, http://www.imf.org/external/np/pp/eng/2013/070213.pdf.

, 2013b, Discussion Paper, "Unconventional monetary policies - recent experience and prospects", April (Washington).

,2013c, IMF policy paper, "Global liquidity_credit and funding indicators", July (Washington).

, 2013d, "Acute Risks Reduced: Actions Needed To Entrench Financial Stability," in Global Financial Stability Report, Chapter 1, April (Washington).

, 2014e, Policy Paper, "Global Liquidity: Issues for Surveillance”, March (Washington).

, 2014f, Global Financial Stability Report, Chapter 2, "How do Changes in the Investor Base and Financial deepening Affect Emerging Market Economies?", April (Washington).

Ivashina, Victoria and David Scharfstein, 2010, "Bank lending during the financial crisis of 2008," Journal of Financial Economics, vol. 97, pp. 319-38.

Iwata, Kazumasa and Shinji Takenaka, 2012, "Central Bank Balance Sheets Expansion: Japan's Experience”, JCER Discussion Paper, No. 134. https://www.jcer.or.jp/eng/pdf/dp134.pdfJoyce, Michael, Matthew Tong and Robert Woods, 2011, “The United Kingdom's quantitative easing policy: design, operation and impact", Bank of England, Quarterly Bulletin, 2011 Q3.

Li, Canlin and Min Wei, 2013, “Term Structure Modeling with Supply Factors and the Federal Reserve's Large-Scale Asset Purchase Programs," International Journal of Central Banking, vol. 9 (March), pp. 3-39, www.ijcb.org/journal/ijcb13q1a1.pdf. 
Kim, Hyun Jeong, Hyun Song Shin, and Jaeho Yun, 2013, "Monetary Aggregates and the Central Bank's Financial Stability Mandate," International Journal of Central Banking, January 2013, pp. 69-107.

Krishnamurthy, Arvind and Annette Vissing-Jorgensen (2011). "The Effects of Quantitative Easing on Interest Rates: Channels and Implications for Policy," Brookings Papers on Economic Activity, vol. 43 (Fall), pp. 215-87.

Nellis, Daniel and Grinnell College, 2013, "Measuring the Change in Effectiveness of Quantitative Easing", Issues in Political Economy, Vol 22, 2013, pp. 108-126.Malloy, Matthew, 2013, "Factors Influencing Emerging Market Central banks' Decision to Intervene in Foreign Exchange Markets," IMF Working Paper, WP/13/70.

McCauley, Robert, Christian Upper, and Agustín Villar, 2013, “Emerging Market Debt Securities Issuance in Offshore Centers" BIS Quarterly Review, September, pp. 2223.

McKinnon, Ronald I., 1982, "Currency Substitution and Instability in the World Dollar Standard," American Economic Review, Vol. 72, No. 3, pp. 320-33.

Meaning, Jack and Feng Zhu, 2012, "The Impact of Federal Reserve Asset Purchase Programmes: Another Twist," BIS Quarterly Review (March), pp. 23-30, www.bis.org/publ/qtrpdf/r_qt1203e.pdf.

Sahay, Ratna, Vivek Arora, Thanos Arvanitis, Hamid Faruqee, Papa N'Diaye, Tommaso Mancini-Griffoli, and an IMF team, 2014, "Emerging market volatility: lessons from the taper tantrum", IMF Staff Discussion Note, September, SDN/14/09.

Shin, Hyun Song and Laura Yi Zhao, 2013, "Non-financial Firms as Surrogate Intermediaries" working paper, Princeton University.

Swanson, Eric T., 2011, "Let's Twist Again: A High-Frequency Event-Study Analysis of Operation Twist and Its Implications for QE2," Brookings Papers on Economic Activity, vol. 42 (Spring), pp. 151-207.

Turner, Philip, 2013, “The global long-term interest rate, financial risks and policy choices in EMEs", paper for the Inter-American Development Bank Meeting of Chief Economists of Central Banks and Finance Ministries, Washington DC, October 2013.

Wintoki, Babajide M., James S. Linck and Jeffry M. Netter, 2012, "Endogeneity and the Dynamics of Internal Corporate Governance," Journal of Financial Economics, Vol. 105, Iss. 3, pp. 581-606. 